http://dx.doi.org/10.11646/zootaxa.3647.1.4

http://zoobank.org/urn:1sid:zoobank.org:pub:ADF115EA-8705-4874-96E7-E76DEAFB4B69

\title{
The amathiiform Ctenostomata (phylum Bryozoa) of New Zealand -including four new species, two of them of probable alien origin
}

\author{
DENNIS P. GORDON ${ }^{1} \&$ MARY SPENCER-JONES ${ }^{2}$ \\ ${ }^{\prime}$ National Institute of Water \& Atmospheric Research, Private Bag 14901, Kilbirnie, Wellington, New Zealand. \\ E-mail: dennis.gordon@niwa.co.nz \\ ${ }^{2}$ The Natural History Museum, Cromwell Road, London SW7 5BD, U.K. E-mail: m.spencer-jones@nhm.ac.uk
}

\begin{abstract}
The status of the vesiculariid ctenostome genus Amathia in New Zealand has been evaluated on the basis of all known material, including historic specimens in museums and those newly collected during formal surveillance of ports, harbours and vessels for possible alien species. Eight species are recognised, four of them new to science. Amathia gracei n. sp. and Amathia zealandica $\mathbf{n}$. sp. are the only apparently endemic species. Amathia chimonidesi n. sp. appears to be a previously unrecognised alien species and is known only from shipping harbours and/or yacht marinas and some nearby beaches. Amathia similis n. sp. has been known in the Auckland area since the 1960s but was confused with A. distans Busk. Amathia bicornis (Tenison-Woods), A. biseriata Krauss, A. lamourouxi Chimonides and A. wilsoni Kirkpatrick are Australasian species that occur naturally on both sides of the Tasman Sea. Of this latter group, A. bicornis was discovered only at a single locality on the southwest coast of North Island in 1983 on a fucoid seaweed and it may be relatively recently self-introduced. A specimen of A. lendigera (Linnaeus) in the Museum of New Zealand, purportedly from Napier, is considered to be based on a misunderstanding or a labelling error and does not represent a failed alien introduction. The Amathia-like vesiculariid Bowerbankia citrina (Hincks) sensu lato is newly recorded for New Zealand. Keys are provided to the amathiiform (i.e. Amathia and Amathia-like) Ctenostomata of New Zealand and to the worldwide species of Amathia and Bowerbankia with zooid clusters spiralled on stoloniform axes.
\end{abstract}

Key words: Bryozoa, Ctenostomata, Amathia, Bowerbankia citrina, new species, introduced species

\section{Introduction}

Amathia Lamouroux, 1812 is a well-known genus of Vesiculariidae that has been reported from all continents except Antarctica. All species have branching colonies, dendroid, bushy or repent, that are made up of stolon segments, separated by septa at nodes, which bear clusters of autozooids. The distinctive feature of the genus, reflected in a later junior synonym (Serialaria Lamarck, 1816), is that the autozooids are seriated in the clusters, occurring in actual or slightly offset pairs that are connate with adjacent autozooids for a considerable part of their height, the connate wall being slightly (or considerably) more cuticularised than the extensible distal part. The genus is known from the latest Mesozoic (Maastrichtian), based on a bioimmured fossil, Amathia immurata Voigt, 1972, which preserves the imprint of spiralled autozooid clusters about a stoloniform axis. Amathia is nested within the confamilial genus Bowerbankia Farre, 1837 in gene trees (Waeschenbach et al. 2012), with an unnamed Amathia species sister to Bowerbankia citrina (Hincks, 1877) from Wales. After accounting for synonyms (Prenant \& Bobin 1956; d'Hondt 1983; Chimonides 1987; Souto et al. 2010), there are at least 31 valid, previously described Amathia species, 16 of which exhibit some degree of spirality of the autozooid clusters on the stolon segments and the balance have the autozooids in more or less straight series (Table 1). Two species of Bowerbankia-B. citrina and B. pustulosa (Ellis \& Solander, 1786) - also have a somewhat spiral disposition of autozooidal clusters and hence appear 'amathiform,' but these zooids are not connate nor are the lateral walls differentially cuticularised. 
TABLE 1. The valid living species of Amathia Lamouroux, 1812 (including new species described herein).

\begin{tabular}{|c|c|c|}
\hline Species & $\begin{array}{l}\text { Disposition of zooid } \\
\text { clusters on stolon }\end{array}$ & $\begin{array}{l}\text { Provenance of labelled holotype and/or as stated } \\
\text { in original description, or of neotype* or } \\
\text { lectotype } \dagger \text { if revised }\end{array}$ \\
\hline A. acervata Lamouroux, 1824 & spiral & Japan Sea $^{1}$ \\
\hline A. aegyptiana d'Hondt, 1983 & spiral & Suez Canal, Egypt ${ }^{1}$ \\
\hline A. alternata Lamouroux, 1816 & straight & *off Cape Fear, North Carolina, USA ${ }^{2}$ \\
\hline A. bicornis Tenison-Woods, 1880 & spiral & SE Australia (Tasmania?) ${ }^{1}$ \\
\hline A. biseriata Krauss, 1837 & straight & *Port Phillip, Victoria, Australia ${ }^{2}$ \\
\hline A. brasiliensis Busk, 1886 & spiral & off Bahia, Brazil ${ }^{1}$ \\
\hline A. brongniartii Kirkpatrick, 1888 & straight & *Port Phillip, Victoria, Australia ${ }^{2}$ \\
\hline A. chimonidesi $\mathbf{n} . \mathbf{s p .}$ & spiral & Auckland Harbour, New Zealand ${ }^{1}$ \\
\hline A. connexa Busk, 1886 & spiral & off Cape York, Queensland, Australia ${ }^{1}$ \\
\hline A. convoluta (Lamarck, 1816) & spiral & Australia $^{1}$ \\
\hline A. crispa (Lamarck, 1816) & spiral & Bass Strait, Australia ${ }^{3}$ \\
\hline A. delicatula Souto et al., 2010 & straight & Punta de la Guardia, Mallorca, Spain ${ }^{1,4}$ \\
\hline A. dichotoma (Verrill, 1873) & spiral & Great Egg Harbor, New Jersey, USA ${ }^{1}$ \\
\hline A. distans Busk, 1886 & spiral & off Bahia, Brazil ${ }^{1}$ \\
\hline A. gracei $\mathbf{n} . \mathbf{s p .}$ & spiral & ENE of East Cape, New Zealand ${ }^{1}$ \\
\hline A. guernseii Chimonides, 1987 & straight & Saints Bay, Guernsey ${ }^{1}$ \\
\hline A. intermedis Chimonides, 1987 & straight & Hastings, England, $\mathrm{UK}^{1}$ \\
\hline A. lamourouxi Chimonides, 1987 & straight & *Port Phillip, Victoria, Australia ${ }^{1}$ \\
\hline A. lendigera (Linnaeus, 1758) & straight & ${ }^{*}$ Chichester Harbour, England, $\mathrm{UK}^{1}$ \\
\hline A. minoricensis Souto et al., 2010 & spiral & Canal de Menorca, Balearic Isles, Spain ${ }^{1,4}$ \\
\hline A. obliqua MacGillivray, 1895 & straight & Port Phillip Heads, Victoria, Australia ${ }^{1}$ \\
\hline A. pinnata Kirkpatrick, 1888 & straight & *Port Phillip, Victoria, Australia ${ }^{2}$ \\
\hline A. plumosa MacGillivray, 1890 & straight & Port Phillip Heads, Victoria, Australia ${ }^{1}$ \\
\hline A. populea Busk in d'Hondt, 1983 & straight & $\dagger$ Natal, South Africa ${ }^{2}$ \\
\hline A. pruvoti Calvet, 1911 & spiral & Mediterranean $^{2}$ \\
\hline A. semiconvoluta Lamouroux, 1824 & spiral & $\dagger$ Mediterranean ${ }^{1,4}$ \\
\hline A. semispiralis (Kirchenpauer, 1869) & spiral & Samoa $^{1}$ \\
\hline A. similis $\mathbf{n}$. $\mathbf{s p .}$ & spiral & Opua, Bay of Islands, New Zealand ${ }^{1}$ \\
\hline A. tortuosa Tenison-Woods, 1880 & spiral & Port Jackson, NSW, Australia ${ }^{1}$ \\
\hline A. tricornis Busk in Chimonides, 1983 & straight & Australia $^{1}$ \\
\hline A. vermetiformis Harmer, 1926 & spiral & E of Salawati Is., West Papua, Indonesia ${ }^{1}$ \\
\hline A. vidovici (Heller, 1867) & spiral & Capocesto (Primošten), Croatia $^{1}$ \\
\hline A. wilsoni Kirkpatrick, 1888 & straight & Port Phillip, Victoria, Australia ${ }^{1}$ \\
\hline A. woodsii Goldstein, 1879 & straight & ${ }^{*}$ Port Jackson, NSW, Australia ${ }^{1}$ \\
\hline A. zealandica $\mathbf{n} . \mathbf{s p}$. & straight & NE of Spirits Bay, New Zealand ${ }^{1}$ \\
\hline
\end{tabular}

1-Original description; 2-Chimonides (1987); 3—d'Hondt (1979); 4-Souto et al. (2010)

Hutton (1873) was the first to describe a species of Amathia from New Zealand, which he mistakenly ascribed to the cheilostome genus Beania Johnston, 1840. He evidently included a sample of the species in a collection of 
bryozoans that he subsequently sent to Eliza C. Jelly in the U.K., who noted in her compendious Synonymic Catalogue (Jelly 1889) that Beania swainsoni Hutton, 1873 is a species of Amathia. Hutton $(1891,1904)$ and Hamilton (1898) then used the combination Amathia swainsoni (Hutton, 1891) in lists of Bryozoa from New Zealand. There were no further published records of the genus in New Zealand until Macken (1956) reported Amathia wilsoni Kirkpatrick, 1888 from Wellington, along with the first (and only) record of an alien introduction, in Napier, of Amathia lendigera (Linnaeus, 1758), a species known only from Europe. In the same work she synonymised A. swainsoni with Amathia biseriata Krauss, 1837, otherwise known only from southern Australia.

Eight years later, Harger (1964) reported Amathia distans Busk, 1886 as a fouling species in Waitemata Harbour, Auckland. This record was noted by Gordon (1967), who observed the same putative species epizoic on the ctenostome Zoobotryon verticillatum (Delle Chiaje, 1822) (as Z. pellucidum [sic] Ehrenberg, 1829). Morton \& Miller (1968, fig. 152) illustrated the species reported by Harger but referred to it in their text (p. 411) as $A$. biseriata. This is also the form from Auckland illustrated by Gordon \& Mawatari (1992) as A. distans in their atlas of marine-fouling Bryozoa of New Zealand ports and harbours. Evidence is presented in this paper that this species is not only not $A$. distans, but represents a previously unrecognised undescribed species that is almost certainly alien in New Zealand.

Gordon (1986) added to the known distribution of A. wilsoni in New Zealand. Chimonides (1987) confirmed the presence of historical material of A. wilsoni and A. biseriata from New Zealand based on specimens in the Natural History Museum, London (NHMUK), and added Amathia lamourouxi Chimonides, 1987 (A. cornuta auctt.), also based on material in NHMUK. The most recent New Zealand Bryozoa checklist (Gordon et al. 2009) has five species of Amathia, including, in addition to the above, Amathia bicornis (Tenison-Woods, 1877) (as A. acervata Lamouroux, 1824, based on a synonymic error in d'Hondt 1983).

The purpose of this paper is to assess the status of all of these species in New Zealand in relation to specimens held in New Zealand museums, the National Institute of Water \& Atmospheric Research (NIWA) invertebrate collection, and NHMUK, as well as recent new material collected in the course of formal surveillance of New Zealand ports and harbours since 2005. Marine life collected during this surveillance (of vessels, structures, and the seabed in the vicinity) is housed at NIWA as part of the Marine Invasives Taxonomic service (MITS) (see Gordon et al. 2008), now funded by the Ministry for Primary Industries. The surveys have turned up specimens of Amathia (and other ctenostomes) that either do not conform to the known species in New Zealand or exhibit morphological characters that suggest they are new to science. One Amathia-like species collected live in Porirua Harbour represents the first record of Bowerbankia citrina sensu lato in New Zealand and the opportunity is taken here formally to record the presence of this taxon also.

\section{Material and methods}

The species studied here were obtained from field collecting by the first author and colleagues or were already lodged in existing museum collections. Specimens that were collected in a partially dried state (beach-cast material), or museum material that had been mounted dry on card, were in some instances reconstituted using aqueous trisodium phosphate and transferred to $70 \%$ ethanol. Morphological features were examined under a binocular microscope and measurements made on preserved material using an eyepiece graticule. The new species described here are lodged in the NIWA Invertebrate Collection (NIC) at the National Institute of Water \& Atmospheric Research, Wellington.

\section{Systematic account}

Order Ctenostomata Busk, 1852

Family Vesiculariidae Johnston, 1838

Genus Amathia Lamouroux, 1812 
Amathia gracei n. sp.

(Figs 1-3, Table 2)

Material examined. Holotype: NIWA 84924, from R.V. Tangaroa cruise TAN1108, Stn $239,37.595^{\circ}$ S, $178.865^{\circ}$ E, ENE of East Cape, North Island, 56-58 m, 1 June 2011. No paratypes.

Etymology. Honorific for Dr Roger V. Grace, Leigh, well-known New Zealand research diver and environmentalist.

Description. Colony erect, bushy and densely branching, to $70 \mathrm{~mm}$ high, with a stout tuft of anchoring rhizoids proximally, brown. Stolon segments gently sinuous rather than straight, mostly $2.7 \mathrm{~mm}$ long, each terminating at a regular dichotomy, the angle between the two branches $30-45^{\circ}$. At each dichotomy, one daughter stolon segment tends to continue in line with the parent and is of the same width (diameter), with the opposing daughter stolon segment frequently of smaller width. Mean stolon width $0.23 \mathrm{~mm}$. Autozooid clusters disposed in an anticlockwise spiral on each stolon segment, comprising c. 16-23 'pairs' per cluster, each cluster describing a complete $360^{\circ}$ circuit of the stolon segment from its commencement to its completion; each cluster has its mean inception $0.52 \mathrm{~mm}$ from the bifurcation, a mean linear distance of $2.29 \mathrm{~mm}$ on the stolon segment, terminating at the next bifurcation; zooid cluster occupying $77-85 \%$ of stolon length. Autozooids all tilted distad c. $30-35^{\circ}$ from the perpendicular, with a mean length of $0.58 \mathrm{~mm}$ in alcohol-preserved retracted specimens, connate; zooid width (as measured in lateral view of zooid cluster) averaging $0.12 \mathrm{~mm}$; owing to the zooid tilt, the distal end of each cluster leans past the point of termination of the zooid insertions at each bifurcation. Outer walls of zooids slightly thicker than interior walls, which are thinnest distally. Polypides and tentacle numbers not observed. Rhizoid originating from a pore at the proximal end of the more proximal stolon segments, each pore occurring just distal to a bifurcation, either laterally on the stolon segment, or on the 'frontal' side proximal to the inception of a zooid series, or on the opposite 'lower' side of the segment, rarely two rootlet pores per stolon segment, opposite each other on the segment.

Remarks. Amathia gracei $\mathbf{n}$. sp. is known only from the type locality and is assumed to be endemic.

Amathia gracei n. sp. resembles Amathia crispa (Lamarck, 1816), a senior synonym of Amathia convoluta Lamouroux, 1816. [Note that, as indicated by d'Hondt (1983), Serialaria convoluta Lamarck, 1816 and Amathia convoluta Lamouroux, 1816 were independent introductions and do not comprise the same species. Further, the former is a senior synonym of Amathia spiralis Lamouroux, 1816. Lamarck's work was published in March 1816 and Lamouroux's in October 1816 according to Sherborn (1922, p. lxxvii).] D'Hondt (1983, pl. 3, fig. 1) and Chimonides (1987, fig. 12D) both illustrated A. crispa, which differs from A. gracei in achieving longer spirals and a longer mean stolon-segment length; also the zigzag angles of the spirals are $60-80^{\circ}$ in $A$. crispa but $101-107^{\circ}$ in A. gracei.

TABLE 2. Metrics for the new species of Amathia described herein $(\mathrm{N}=20$ for zooid dimensions; $\mathrm{N}=10-20$ for other characters).

\begin{tabular}{|c|c|c|c|c|c|c|c|c|}
\hline New species & $\begin{array}{l}\text { Zooid } \\
\text { length: } \\
\text { range, } \\
\text { mean, (SD) } \\
(\mathrm{mm})\end{array}$ & $\begin{array}{l}\text { Zooid } \\
\text { width: } \\
\text { range, } \\
\text { mean, (SD) } \\
(\mathrm{mm})\end{array}$ & $\begin{array}{l}\text { Stolon } \\
\text { width: } \\
\text { range, } \\
\text { mean, (SD) } \\
(\mathrm{mm})\end{array}$ & $\begin{array}{l}\text { Stolon } \\
\text { length*: } \\
\text { range, } \\
\text { mean (SD) } \\
(\mathrm{mm})\end{array}$ & $\begin{array}{l}\text { Cluster } \\
\text { length: } \\
\text { range, } \\
\text { mean, (SD) } \\
(\mathrm{mm})\end{array}$ & $\begin{array}{l}\text { Cluster } \\
\text { inception: } \\
\text { range, } \\
\text { mean, (SD) } \\
(\mathrm{mm})\end{array}$ & $\begin{array}{l}\% \text { of stolon } \\
\text { occupied by } \\
\text { zooid } \\
\text { cluster }\end{array}$ & $\begin{array}{l}\text { Number of } \\
\text { zooid } \\
\text { 'pairs' }\end{array}$ \\
\hline chimonidesi & $\begin{array}{l}0.52-0.62 \\
0.57 \\
(0.0255)\end{array}$ & $\begin{array}{l}0.10-0.15 \\
0.13 \\
(0.0117)\end{array}$ & $\begin{array}{l}0.18-0.30 \\
0.25 \\
(0.0335)\end{array}$ & $\begin{array}{l}3.54-6.22 \\
4.68 \\
(0.6810)\end{array}$ & $\begin{array}{l}3.07-4.61 \\
3.67 \\
(0.4433)\end{array}$ & $\begin{array}{l}0.33-1.53 \\
1.06 \\
(0.3908)\end{array}$ & $67-$ & $24-32$ \\
\hline gracei & $\begin{array}{l}0.47-0.61 \\
0.58 \\
(0.0345)\end{array}$ & $\begin{array}{l}0.09-0.15 \\
0.12 \\
(0.1150)\end{array}$ & $\begin{array}{l}0.15-0.30 \\
0.23 \\
(0.0519)\end{array}$ & $\begin{array}{l}2.58-2.93 \\
2.71 \\
(0.1550)\end{array}$ & $\begin{array}{l}1.90-2.52 \\
2.29 \\
(0.2205)\end{array}$ & $\begin{array}{l}0.40-0.67 \\
0.52 \\
(0.0859)\end{array}$ & $77-85$ & $16-23$ \\
\hline similis & $\begin{array}{l}0.39-0.56 \\
0.49 \\
(0.0498)\end{array}$ & $\begin{array}{l}0.10-0.18 \\
0.15 \\
(0.0248)\end{array}$ & $\begin{array}{l}0.15-0.24 \\
0.20 \\
(0.0234)\end{array}$ & $\begin{array}{l}2.48-3.47 \\
2.95 \\
(0.3145)\end{array}$ & $\begin{array}{l}1.01-1.52 \\
1.29 \\
(0.1381)\end{array}$ & $\begin{array}{l}1.46-2.20 \\
1.65 \\
(0.2322)\end{array}$ & $36-49$ & $6-14$ \\
\hline zealandica & $\begin{array}{l}0.46-0.58 \\
0.52 \\
(0.0342)\end{array}$ & $\begin{array}{l}0.10-0.15 \\
0.13 \\
(0.0123)\end{array}$ & $\begin{array}{l}0.11-0.24 \\
0.17 \\
(0.0412)\end{array}$ & $\begin{array}{l}1.62-2.88 \\
2.42 \\
(0.3095)\end{array}$ & $\begin{array}{l}0.90-1.96 \\
1.62 \\
(0.2813)\end{array}$ & $\begin{array}{l}0.44-0.77 \\
0.58 \\
(0.1157)\end{array}$ & $57-75$ & $7-14$ \\
\hline
\end{tabular}

\footnotetext{
* between branch nodes (single segments only)
} 

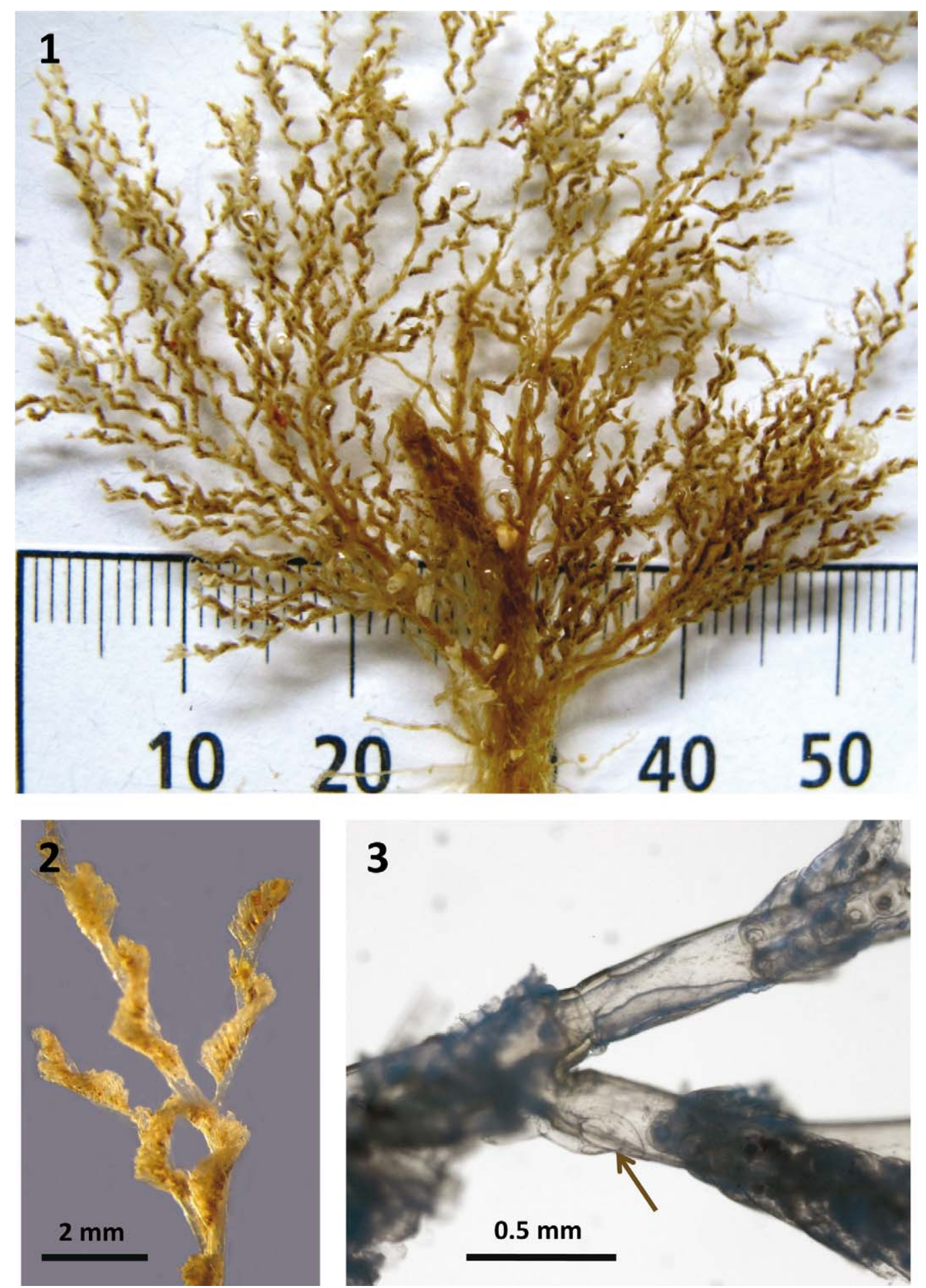

FIGURES 1-3. Amathia gracei n. sp. 1, holotype colony from ENE of East Cape, North Island; 2, part of colony showing zigzagged clusters of autozooids; 3 , branch bifurcation with a rhizoid pore arrowed.

\section{Amathia similis n. sp.}

(Figs 4-8, Table 2)

Amathia biseriata: Morton \& Miller 1968: 411, 413, fig. 152. Non Krauss, 1837.

Amathia distans: Gordon, 1967: 48, fig. 5 (figure copied from Prenant \& Bobin 1956); Gordon \& Mawatari 1992: 11, fig. 2 C, pl. 5B; Morton 2004: 272; Gordon et al. 2009: 288. Non Busk, 1886. 

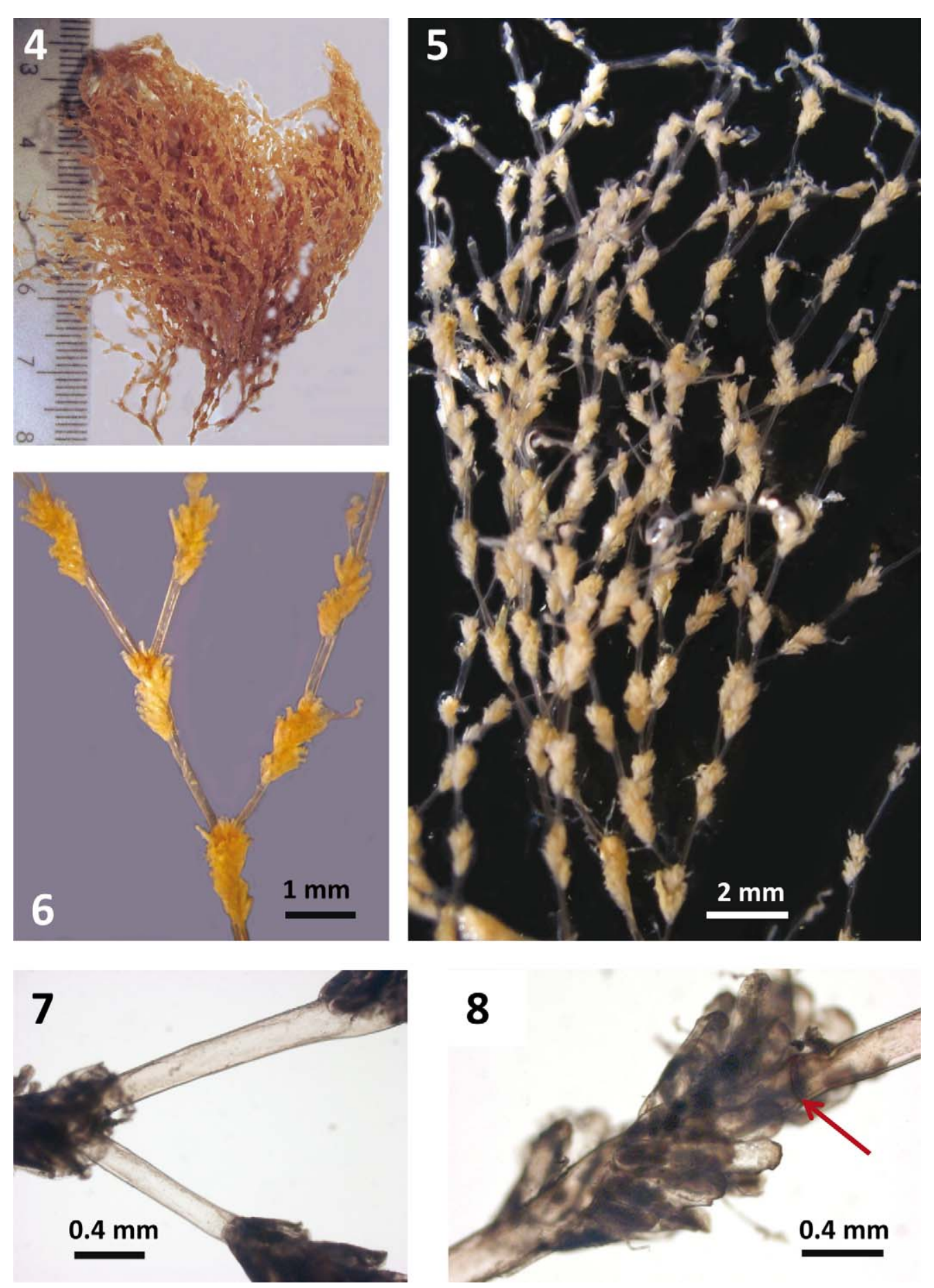

FIGURES 4-8. Amathia similis n. sp. 4, holotype colony from Opua marina, Bay of Islands, North Islands; 5, close-up of branches with tightly spiralled clusters of autozooids; 6 , autozooid clusters on stolons; 7 , branch bifurcation; 8, autozooid cluster, with position of stolon septum arrowed.

Material examined. Holotype: NIWA 84931, comprising OPX11163-HY, MITS Cat. \# 69732, from the Opua marina, Bay of Islands, New Zealand, $35.3137^{\circ} \mathrm{S}, 174.1223^{\circ} \mathrm{E}$, collected 8 September 2010, from a starfish trap deployed overnight at $5 \mathrm{~m}$ depth, specimen caught up in trap mesh. Other material: MNK208-BR, MITS Cat. \#19676, in channel immediately south of Wesley Bay, Manukau Harbour, New Zealand, $36.936^{\circ} \mathrm{S}, 174.7443^{\circ} \mathrm{E}$, collected 15 June 2006, c. 6-7 m depth. No paratypes.

Etymology. Latin, similis, like, resembling, alluding to its similarity with A. distans.

Description. Colony erect, bushy and densely branching, to $87 \mathrm{~mm}$ high, with no anchoring rhizoids, pale brown. Stolon segments straight, mostly $3.0 \mathrm{~mm}$ long, mostly terminating at a dichotomy, the angle between the 
two branches $40-60^{\circ}$. At each dichotomy, one daughter stolon segment may continue in line with the parent, with the other branching at an angle from the node, but this is not consistent and is often unclear owing to overlap of the node by the distalmost zooids in a cluster. Alternatively, there may be 2-3 stolon segments between dichotomies. Mean stolon width $0.20 \mathrm{~mm}$. Autozooid clusters disposed in tight spirals, each either clockwise or anticlockwise on a stolon segment, comprising c. 6-14 'pairs' per cluster, each cluster describing between one and two complete circuits $\left(360-720^{\circ}\right)$ of the segment from its commencement to its completion (rarely only $320-360^{\circ}$ ). The spirality of the parent-stolon cluster is maintained in both daughter stolon segments, whether clockwise or anticlockwise. Each cluster has its mean inception $1.65 \mathrm{~mm}$ from a bifurcation or stolon septum, a mean linear distance of 1.29 $\mathrm{mm}$ on the stolon segment, terminating at the next bifurcation or septum; zooid cluster occupying only $36-49 \%$ of stolon-segment length. Autozooids all tilted distad c. $20-45^{\circ}$ from the perpendicular, with a mean length of 0.49 $\mathrm{mm}$ in alcohol-preserved retracted specimens, connate; zooid width (as measured in lateral view of zooid cluster) averaging $0.15 \mathrm{~mm}$; owing to the zooid tilt, the distal end of each cluster leans past the point of termination of the zooid insertions at each bifurcation. Outer walls of zooids slightly thicker than interior walls, which are thinnest distally. Polypides and tentacle numbers not observed. No rhizoids.

Remarks. In New Zealand, colonies of similar form from Waitemata Harbour and shores to the east of the harbour have been attributed to A. distans Busk, 1886 [see Gordon \& Mawatari (1992) for New Zealand literature summary]. Amathia similis shares with Amathia aegyptiana d'Hondt, 1983 and A. distans a lack of rhizoids but, like A. aegyptiana and Amathia brasiliensis Busk, 1886, maintains spirality of the autozooid cluster from the parent stolon to both daughter stolon segments; it differs from A. aegyptiana in having a much smaller mean stolon diameter and consistently fewer autozooid pairs (see key). Amathia similis differs, inter alia, from A. distans in maintaining the direction of spirality in mother and daughter branches and in having a greater stolon diameter (comparative dimensions non-overlapping-cf. Fehlauer-Ale et al. 2011). In autozooid and stolon dimensions, $A$. similis is similar to A. brasiliensis, but differs from it in having a smaller occupancy of the autozooid cluster on the stolon segments (only $36-49 \%$ compared to $57-72 \%$ ) and no rhizoids.

It is unlikely that A. similis n. sp. is native to New Zealand, having been found only at or adjacent to ports frequented by merchant and recreational vessels. D'Hondt (1983) and Fehlauer-Ale et al. (2011) have noted measurable variation in specimens attributed to A. distans in museum collections and in the literature, indicative of unrecognised species, with A. similis possibly among them. MacGillivray (1895) described putative A. distans from South Australia and Harmer (1915) likewise from Indonesia. Both authors described or illustrated autozooid clusters as occupying $50 \%$ of the stolon segments with anticlockwise spirality on both parent and daughter stolons (which rules out genuine A. distans, first described from the state of Bahia, Brazil); on the other hand, MacGillivray depicted approximately 13-17 autozooids per cluster compared to 8-12 in Harmer so it is unclear if their material is conspecific. MacGillivray's scale (not on the same plate as his illustration) seems inconsistent with his magnified figure so the dimensions are uncertain. Harmer (1915) gives some dimensions in his text and a scalebar for his drawings-thus autozooid length is $0.45-0.50 \mathrm{~mm}$ and the width is $0.10-0.14 \mathrm{~mm}$; stolon-segment length is $1.6 \mathrm{~mm}$ and width $0.10 \mathrm{~mm}$. The stolon dimensions indicate that Harmer's material is also not conspecific with either A. brasiliensis or A. similis n. sp. New collecting of fresh material from the published localities, accompanied by gene sequencing, would clarify the status of these various morphologies.

Amathia chimonidesi n. sp.

(Figs 9-13, Table 2)

Material examined. Holotype: NIWA 84928, comprising AKL11046-HY, MITS Cat. \# 69772, from western Waitemata Harbour, east of Soldiers Bay, Auckland, $36.8151^{\circ} \mathrm{S}, 174.6815^{\circ} \mathrm{E}$, collected 22 December 2010, from a benthic sled, 5 m depth on mud. Paratype: NIWA 84929, from North Head, Waitemata Harbour, Auckland, fresh beach-cast material, collected by Dr Roger V. Grace, 11 April 2003. Other material: NIWA 84930, from North Head, Auckland, beach-cast material collected by D.P. Gordon and K.J. Tilbrook, 12 September 2004.

Etymology. Honorific for Pantelakis J. Chimonides, Natural History Museum, London, who made a significant contribution to resolving the systematics of non-spiralled Amathia. 

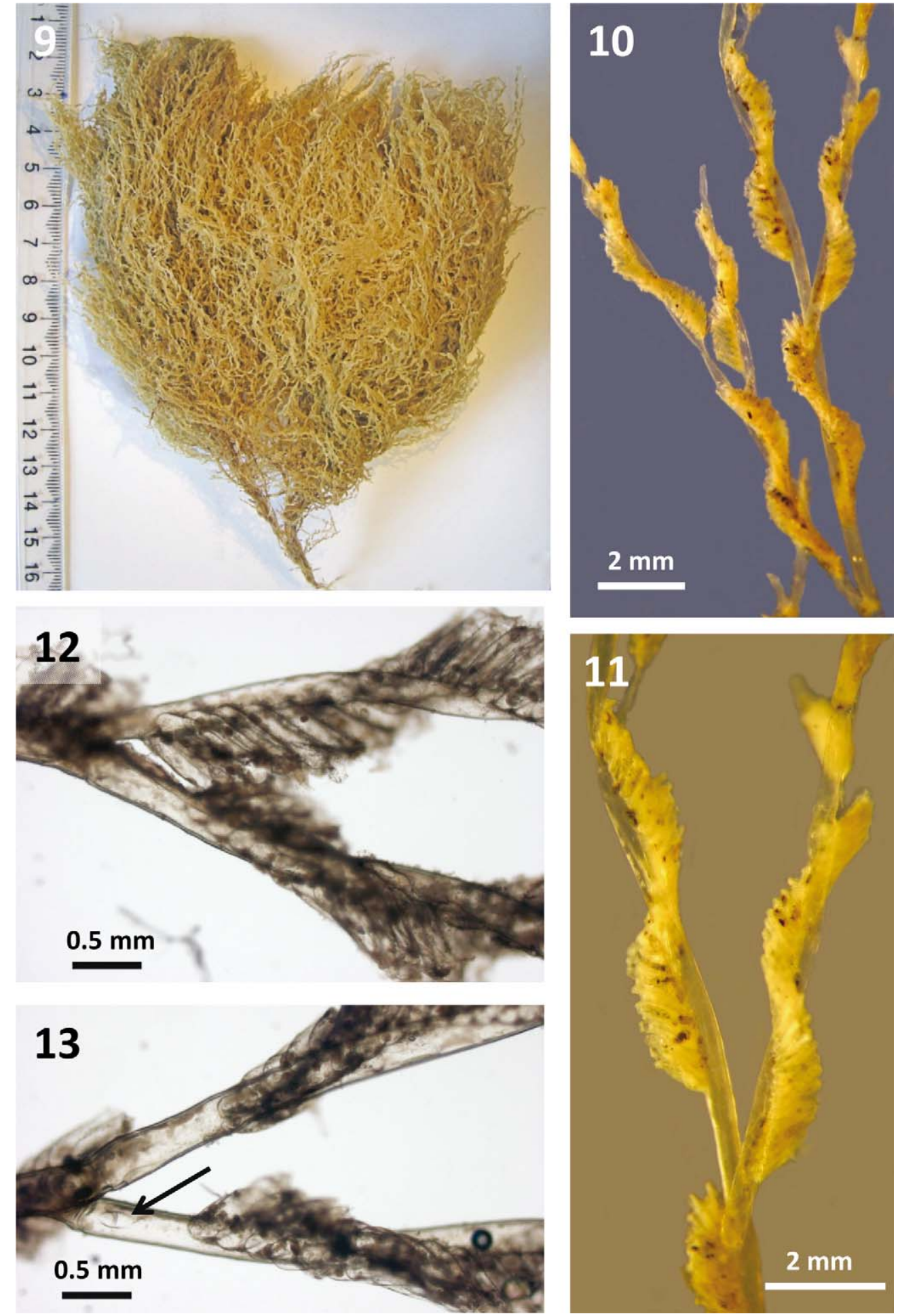

FIGURES 9-13. Amathia chimonidesi n. sp. 9, holotype colony from western Waitemata Harbour, Auckland; 10, close-up of branches with long open spirals of autozooids; 11, same, magnified; 12, 13, branch bifurcations, with a rhizoid pore arrowed in 13.

Description. Colony erect, very bushy and densely branching to $168 \mathrm{~mm}$ high, with a stout tuft of anchoring rhizoids proximally, individual branches pale brown (viewed on white background) to brown (entire colony). Stolon segments almost straight between nodes (the shorter ones), or very gently curving or even sinuous, averaging $4.7 \mathrm{~mm}$ long, each terminating at a regular dichotomy, the angle between the two branches $20-80^{\circ}$. At each dichotomy, one daughter stolon continues in line with the parent stolon, with the parent stolon frequently slighter wider than the daughter. Mean stolon diameter (width) $0.25 \mathrm{~mm}$. Autozooid clusters disposed in a 
clockwise spiral on each stolon segment, comprising 24-32 'pairs', each cluster describing a complete $360^{\circ}$ circuit of the stolon segment from its commencement to its completion; mean inception of each cluster $1.06 \mathrm{~mm}$ from the bifurcation, a mean linear distance of $3.67 \mathrm{~mm}$ on the stolon segment, terminating at the next bifurcation; zooid cluster occupying $67-96 \%$ of stolon length between branch nodes. Autozooids tilted distad c. $20-50^{\circ}$ from the perpendicular, with a mean length of $0.57 \mathrm{~mm}$ in alcohol-preserved retracted specimens, connate; zooid width (as measured in lateral view of zooid cluster) averaging $0.13 \mathrm{~mm}$; owing to the zooid tilt, the distal end of each cluster leans past the point of termination of the zooid insertions at each bifurcation. Outer walls of zooids slightly thicker than interior walls, which are thinnest distally. Polypides and tentacle numbers not observed. Rhizoid originating from a pore at the proximal end of the more proximal stolon segments, each pore occurring just distal to a bifurcation in a 'laterofrontal' position, often two rhizoid pores per stolon segment in more proximal parts of the colony.

Remarks. Amathia chimonidesi $\mathbf{n}$. sp. is most similar in the sum of its characters to A. gracei $\mathbf{n}$. sp., differing from it most obviously in the maximum number of autozooid 'pairs' (32 instead of 23-24) and direction of spirality of autozooid clusters throughout the colony (clockwise instead of anticlockwise). [Note, however, that spirality can vary within a species and a colony and only a single specimen of A. gracei was available for determining characters.] Also the spirals in A. gracei are more 'angular' compared to the sinuous spirals in A. chimonidesi.

Amathia chimonidesi n. sp. resembles published illustrations of Amathia semiconvoluta Lamouroux, 1824 from the Adriatic (Heller 1867), the western Mediterranean (Prenant \& Bobin 1956) and Atlantic coast of the Iberian Peninsula (Souto et al. 2010). However, Prenant \& Bobin (1956, in key on p. 279 but not in text) noted that there may be 2-6 stolon segments between dichotomies and Souto et al. (2010) confirmed up to three. The autozooid clusters on these segments may be separated only by short gaps, giving the impression of a single very long cluster between dichotomies. This is not the case in A. chimonidesi.

The figures in Prenant \& Bobin (1956), reproduced from three earlier authors, also show both clockwise and anticlockwise spirals, and Chimonides (1987, figs 5A, 13C, respectively) shows anticlockwise and clockwise spirals, with quite a large gap on the stolon proximally before the spirals begin, raising the question of conspecificity of all the illustrated material, although Souto et al. (2010) noted that individual colonies may be either wholly clockwise or anticlockwise. Both of two large colonies of A. chimonidesi from Auckland have consistently clockwise spirals. Dr Javier Souto (Universidade de Santiago de Compostela, Spain) was sent photographs and a description of A. chimonidesi and he concludes that it is not conspecific with A. semiconvoluta. Mean and maximum stolon lengths (i.e. between branch nodes) are respectively $23-43 \%$ and $22-46 \%$ greater in $A$. chimonidesi and mean and maximum cluster lengths $33-40 \%$ and $36-46 \%$ greater in A. chimonidesi than in A. semiconvoluta, based on Souto et al.'s (2010) data for lectotype and northwestern Iberian material.

The only known occurrences of this species are as large colonies-one from western Waitemata Harbour, and beach-cast material at the south end of Narrow Neck beach adjacent to North Head, Waitemata Harbour, Auckland. Samples of the latter, evidently originating from the sublittoral zone, were collected on 11 April 2003 (R.V. Grace) and 11 September 2004 (D.P. Gordon and K.J. Tilbrook). There was so much cast ashore at times, in extensive thick drifts, that local residents were complaining in a community newspaper about "the continual row of decomposing material along the high tide mark after storms or easterlies" and the "flies resulting from the debris" that was mistaken for a hydroid (Anon. 2005).

It is almost certain that $A$. chimonidesi n. sp. represents a previously unrecognised alien species with an unknown native distribution, especially since it had never been reported in New Zealand before its discovery in a major shipping harbour just under a decade ago.

\section{Amathia biseriata Krauss, 1837}

(Figs 14-18)

Amathia biseriata Krauss, 1837: 23, fig. 1a-c; Waters 1887a: pl. 6, fig. 25; Waters 1887b: 264; MacGillivray 1895: 137, pl. B, fig. 4; Macken 1956: 19, figs 1-2; Chimonides 1987: 330, figs 4B, 11C,D (cum syn.).

Beania swainsoni Hutton, 1873: 91; Hutton 1880: 185; Jelly 1889: 17.

Amathia inarmata MacGillivray, 1887: 183; MacGillivray 1889: 309, p. 185, figs 4, 4a; d'Hondt 1983: 67, fig. 36G.

Amathia swainsoni: Hutton 1891: 107; Hamilton 1898: 194, 197; Hutton 1904: 294. 

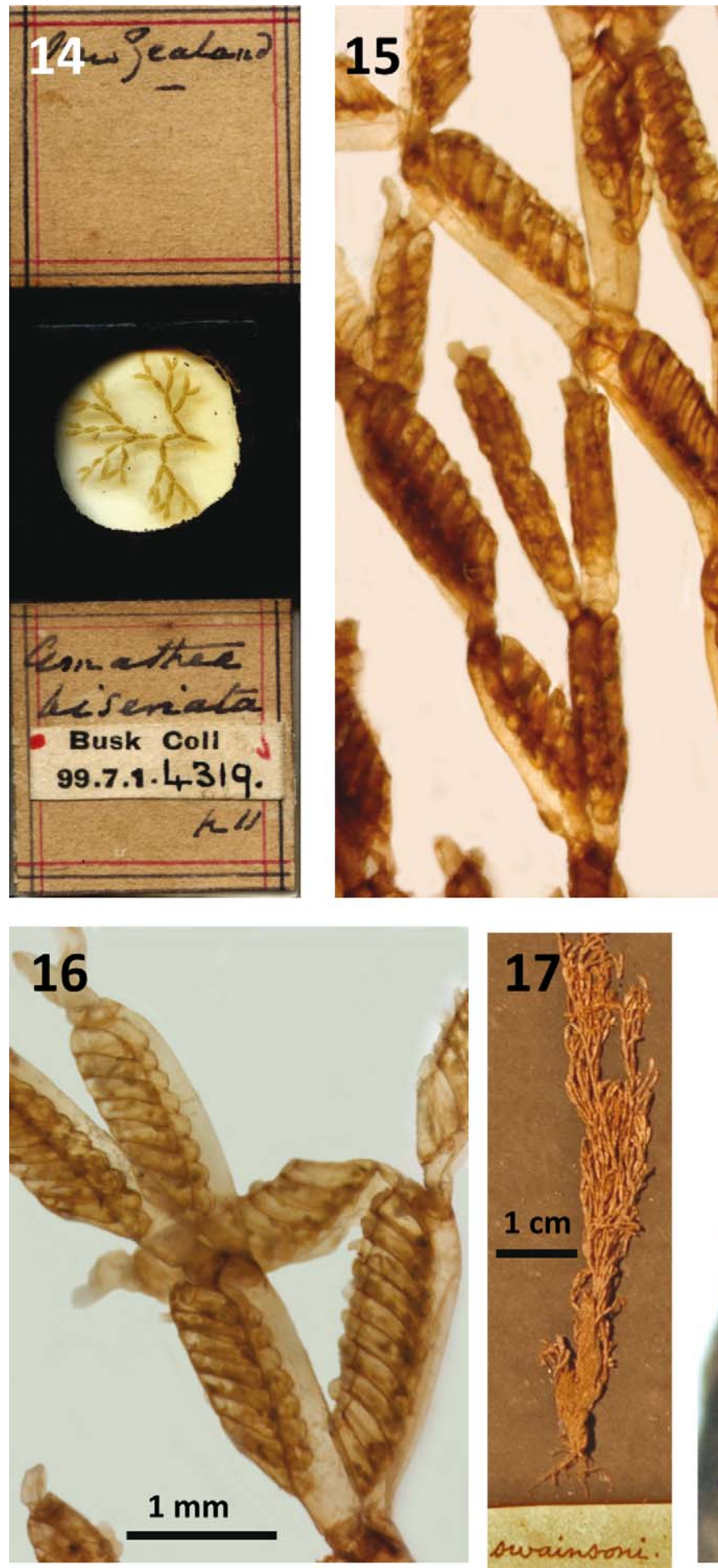

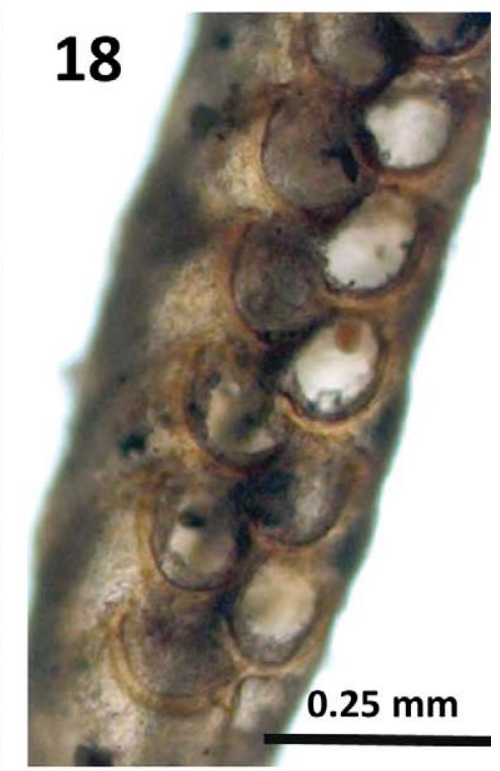

FIGURES 14-18. Amathia biseriata Krauss, 1837. 14, slide of a specimen from New Zealand in the collection of the Natural History Museum, London; 15, close-up of same showing straight clusters of autozoids on the stolon segments; 16, same, showing the frontal distal curvature of stolon segments; 17, specimen A.88.95 labelled Beania swainsoni, Otago Museum, Dunedin. 18, close-up of autozooids showing semicircular, distal cuticularised thickening of rims in the lectotype (NMNZ Pz. 14) of A. swainsoni in the Museum of New Zealand Te Papa Tongarewa.

Material examined. Museum of New Zealand Te Papa Tongarewa: NMNZ Pz. 14, holotype (so designated by Macken 1956, but actually lectotype) of Beania swainsoni, no locality data but presumably from Cook Strait (fide Hamilton 1898); rehydrated from the dried state using aqueous trisodium phosphate, and now preserved in $70 \%$ ethanol. Otago Museum: A.88.95, dried card-mounted Hutton specimen labelled "Beania swainsoni", no locality data but presumably from Dunedin area (fide Hamilton 1898). Otago Museum: A.88.96, two small dried colony 
fragments labelled "Beania swainsoni" in a welled cardboard slide, no locality data but presumably from Dunedin area (fide Hamilton 1898). Natural History Museum, London: NHMUK 1899.7.1.4319, Busk Collection, New Zealand, labelled "Amathia biseriata," 1899.7.1.4401, Busk Collection, ?New Zealand, labelled "Amathia inarmata," and 1899.7.1.4400, Busk Collection, ?New Zealand, labelled "Amathia unilateralis" (a species of Lamouroux 1816).

Description [of A. swainsoni lectotype]. Colony portion branching, $58 \mathrm{~mm}$ high, with a stout tuft of rhizoids constituting the proximal half, brown. Stolon segments straight or very gently arching convexly on the lower side, averaging $2.3 \mathrm{~mm}$ long (range 2.04-2.69 mm), each generally terminating at a dichotomy, the angle between the two branches generally $30-45^{\circ}$. Mean stolon width $0.279 \mathrm{~mm}$ (range $0.235-0.314 \mathrm{~mm}$ ). Autozooid clusters disposed in straight rows on the stolons, but, along the principal stolon axis, successive daughter clusters orientated a little more obliquely (ca. 22\%) than the preceding one, such that every fourth cluster is more or less at right angles to the original. Where branching takes place, the daughter stolon segment tending to be a little narrower proximally than the opposing primary stolon, branching at an angle of $20-45^{\circ}$. Autozooids number $6-11$ pairs in each cluster, clusters having their mean inception $0.443 \mathrm{~mm}$ (range $0.302-0.818 \mathrm{~mm}$ ) from the joint, a mean linear distance of $1.77 \mathrm{~mm}$ (range 1.41-2.11 $\mathrm{mm}$ ) on the stolon, the bases of the distalmost autozooids terminating just short of the next bifurcation; distal tip of stolon segment frequently curving frontally and often connate with the distalmost autozooid; zooid cluster occupying 60-94\% (mean 79\%) of stolon length. Autozooids all tilted distad, the proximalmost ca. $45^{\circ}$ from the perpendicular, the distalmost $20-45^{\circ}$, with a mean length of $0.453 \mathrm{~mm}$ (range $0.390-0.470 \mathrm{~mm}$ ) in alcohol-preserved retracted specimens, connate, each with a conspicuous semicircle of cuticular thickening of the outer rim, the line of thickening at the same level in each zooid, forming a continuous band when the cluster is viewed from the side; zooid width averaging $0.125 \mathrm{~mm}$ (range $0.095-0.140 \mathrm{~mm}$ ). Polypides and tentacle numbers not observed. Rhizoids originating from pores at the proximal end of the more proximal stolon segments, each pore occurring laterally in the segment relative to the dichotomy and the daughter cluster.

Remarks. If one uses Chimonides' (1987) key to the non-spiralled species of Amathia, Hutton's species keys out to A. biseriata. Indeed, Macken (1956) concluded as much based on her examination of Hutton's material (which she designated holotype) in the then Dominion Museum, comparing it with MacGillivray's (1895) description and figures. The published illustrations of Krauss (1837) and MacGillivray $(1889,1895)$ accentuate the convex curvature of the abfrontal side of the stolon segments bearing the autozooids, especially distally in the case of Krauss (1837, fig. 1c) and the short autozooid-free portion of each stolon. In Hutton's limited material, stolon segments are mostly more or less straight or with gentle curvature, with an upturned distal end. Chimonides (1987, fig. 4B) schematically depicts the stolon segments as mostly straight with only a distal curvature, bending around the distal end of the autozooid cluster; as he also described, this is not the case in every stolon segment and MacGillivray (1895) likewise remarked that the "amount of curvature of the internodes varies, some being almost straight." Hutton's material greatly resembles the proximal parts of the colony illustrated in Chimonides' (1987) figure 11C and the inception of the rhizoid in his figure 11D. In the event, perhaps the most striking characteristic of A. biseriata, at least among the New Zealand species of Amathia, is the conspicuous dark band of strong cuticularisation of the distal rim of each autozooid in the cluster. MacGillivray (1889, pl. 185, fig. 4a) depicts the cuticularisation as a ring, which may be a misinterpretation; certainly in Hutton's material it is semicircular, in the proximolateral side of each zooid rim.

There are some metric differences between Hutton's material of A. swainsoni in the Museum of New Zealand Te Papa Tongarewa and the figures given by Chimonides (1987) for A. biseriata (presumably based on the neotype from Port Phillip Bay, Victoria). Mean stolon diameter is $0.32 \mathrm{~mm}$ in the latter but only $0.279 \mathrm{~mm}$ in the former (range $0.235-0.314 \mathrm{~mm}$ ); mean stolon length between branch nodes is $2.05 \mathrm{~mm}$ in the latter but 2.277 (range $2.038-2.688 \mathrm{~mm}$ ) in the former. Mean autozooid length is only $0.35 \mathrm{~mm}$ according to Chimonides, whereas in Hutton's material it ranges from $0.390-0.470 \mathrm{~mm}$ with a mean of $0.453 \mathrm{~mm}$. Metrics for all other characters are very similar or overlap.

Chimonides' (1987) attribution of A. biseriata to the New Zealand fauna is based on only one certain record from New Zealand (NHMUK: registered number 1899.7.1.4319) without precise locality details. Hutton's (1873) material, "from the collection of the late W. Swainson, Esq.," has no accompanying locality data either and none of his publications shed any light on the subject. In the 1880s, Augustus Hamilton collected bryozoans from a number of localities in New Zealand and sent them to Miss E.C. Jelly in Bristol, England, who forwarded them to experts 
for identification so it seems likely that she herself did not identify them although, against entry 116, Beania swainsoni, in her synonymic catalogue, it states "is a species of Amathia". Hamilton's (1898) tabulated list has two entries for Hutton's species, one as "Beania (Amathia ?) swainsoni" from Dunedin (p. 194) and a second as "Amathia swainsoni" from Wellington and Dunedin (p. 197). According to his introductory explanation (p. 192), bryozoan specimens from Wellington were "collected at various times on the shores of Cook Strait" and those from Dunedin were "littoral species collected at various times". NHMUK specimen 1899.7.1.4319 was thus likely sent by Hamilton. [Jelly specimens now reside in NHMUK.] There are no $20^{\text {th }}$ or $21^{\text {st }}$ century records or collections of the species from New Zealand and it remains unclear if the earlier records were based on short-lived alien incursions or self-introductions.

\section{Amathia zealandica n. sp.}

(Figs 19-21, Table 2)

Material examined. Holotype: NIWA 84925, from NIWA Stn Z9676, 34.364 S, $172.841^{\circ} \mathrm{E}$, NE of Spirits Bay, North Island, 57 m, 25 January 1999. Paratype: NIWA 84926, from NIWA Stn Z9677, $34.319^{\circ}$ S, $172.825^{\circ}$ E, 55 m, NE of Spirits Bay, North Island, 25 January 1999. Other material: NIWA 84927, from NIWA R.V. Tangaroa cruise 1108, Stn $213\left(37.546^{\circ} \mathrm{S}, 178.896^{\circ} \mathrm{E}\right.$, east of East Cape, North Island, 68-70 m, 30 May 2011); also NIWA 75476, TAN1108/233 (37.601 ${ }^{\circ} \mathrm{S}, 178.894^{\circ} \mathrm{E}$, east of East Cape, North Island, 50-60 m, 31 May 2011), and NIWA 75503, TAN1108/239 (37.595 $\mathrm{S}, 178.865^{\circ} \mathrm{E}$, east of East Cape, North Island, 56-58 m, 1 June 2011).

Etymology.The name reflects the species' status as a New Zealand endemic.

Description. Colony erect, bushy and densely branching, to $66 \mathrm{~mm}$ high, with a stout tuft of anchoring rhizoids proximally, pale brown. Stolon segments straight or very gently arching concavely or convexly on the lower side, the shortest ones showing slightly more convexity; averaging $2.4 \mathrm{~mm}$ long, each terminating at a regular dichotomy, the angle between the two branches generally $40-45^{\circ}$, although angles of $60^{\circ}$ and $80^{\circ}$ have been encountered. Mean stolon width $0.17 \mathrm{~mm}$. Autozooid clusters disposed in straight rows on the stolons, those on one daughter stolon having nearly the same orientation as the parent stolon, those on the other inclined at an angle of c. $25-45^{\circ}$ from the perpendicular towards the adjacent cluster; comprising 7-14 'pairs' per cluster. Each cluster has its mean inception $0.58 \mathrm{~mm}$ from the bifurcation, a mean linear distance of $1.62 \mathrm{~mm}$ on the stolon and terminates at the next bifurcation; distal tip of stolon segment frequently curving frontally and connate with the distalmost autozooid; zooid cluster occupying c. 57-75\% of stolon length. Autozooids all tilted distad, the proximalmost ca. $10-15^{\circ}$ from the perpendicular, the distalmost c. $45^{\circ}$, with a mean length of $0.52 \mathrm{~mm}$ in alcohol-preserved retracted specimens, connate, with outer walls slightly thicker than interior walls; zooid width (as measured in lateral view of zooid cluster) averaging $0.13 \mathrm{~mm}$. Polypides and tentacle numbers not observed. Rootlets originating from pores at the proximal end of the more proximal stolon segments, each pore occurring on the opposite 'lower' side of the segment.

Remarks. As with Hutton's (1873) type specimen of A. swainsoni, the present material also keys out to A. biseriata Chimonides' (1987) key, but there are a number of differences. The most distinctive feature of $A$. biseriata is the conspicuous semicircular cuticularised thickening of the autozooidal rim and this is completely lacking in A. zealandica $\mathbf{n}$. sp., which is also less robust (especially the autozooids) and paler in appearance when samples of the two species are seen side by side in the same microscope field. Likewise there is no marked curvature of the abfrontal surface of the stolon segments as seen in profile compared to typical Australian material of A. biseriata. The first and obvious impression on viewing a colony of A. zealandica is of long narrow zooid clusters on straight stolon segments. Chimonides (1987) made a distinction between daughter stolons produced linearly and laterally from the parent stolon but there is no consistent distinction in A. zealandica. In cases where there is distal curvature of the stolon, one daughter stolon continues beyond the septum behind the distalmost zooid while the other stolon is produced from a septum that is generally 'below' (in a topological sense) the distalmost zooid; nevertheless, the net result is that the daughter zooid cluster distal to any curvature has nearly more or less the same orientation as the parent-stolon cluster and the other is somewhat inclined towards it.

There are other differences, mostly metric, summarised in Table 3 below.

Chimonides (1987) did not give ranges for his metric data. From the above tabulation, A. zealandica $\mathbf{n}$. sp. has longer and thinner stolon segments (internodes) and longer zooids, on average, than Australian A. biseriata. The 
orientation of autozooids in the clusters also differs; all are inclined distad, but, whereas the proximal zooids of $A$. biseriata are generally inclined at an angle of $45^{\circ}$ from the perpendicular, those of A. zealandica are more upright, inclining only $10-15^{\circ}$.

Amathia zealandica $\mathbf{n}$. sp. is known only from the far north and east of North Island, New Zealand, at depths of $50-60 \mathrm{~m}$.
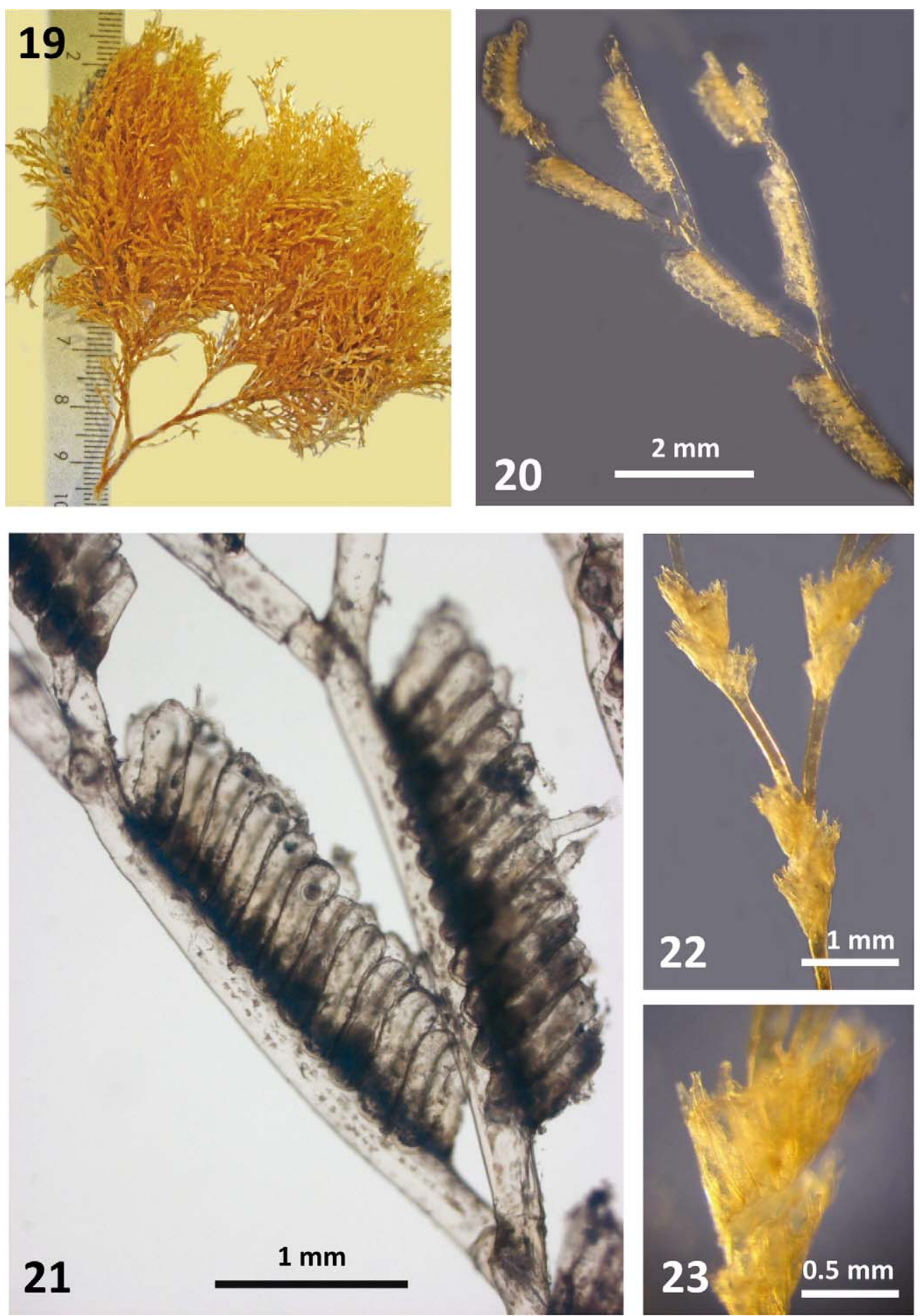

FIGURES 19-23. Amathia zealandica n. sp. 19, colony from NIWA Stn TAN1108/213, E of East Cape, North Island; 20, close-up of same showing straight clusters of autozoids on the stolon segments; 21, same, branch bifurcations and autozooidal clusters. 22, 23, Amathia bicornis (Tenison-Woods, 1877) from Makara Beach, west coast, Wellington region, North Island, showing autozooidal spirals with cuticularisation of autozooids and distal 'horns'. 
TABLE 3. Metric differences between Amathia zealandica n. sp. and A. biseriata Krauss.

\begin{tabular}{lllllll}
\hline Material & $\begin{array}{l}\text { Mean stolon } \\
\text { length }(\mathrm{mm})\end{array}$ & $\begin{array}{l}\text { Mean stolon } \\
\text { width }(\mathrm{mm})\end{array}$ & $\begin{array}{l}\text { Mean zooid } \\
\text { length }(\mathrm{mm})\end{array}$ & $\begin{array}{l}\text { Mean zooid } \\
\text { width }(\mathrm{mm})\end{array}$ & $\begin{array}{l}\text { \% of stolon } \\
\text { occupied by } \\
\text { zooid cluster }\end{array}$ & $\begin{array}{l}\text { No. of } \\
\text { zooid 'pairs' }\end{array}$ \\
\hline A. biseriata $^{1}$ & 2.05 & 0.32 & 0.35 & 0.11 & 75 & $4-12$ \\
A. biseriata & 2.28 & 0.28 & 0.45 & 0.13 & $60-94$ & $8-10$ \\
A. zealandica n. sp. & 2.42 & 0.17 & 0.52 & 0.12 & $57-75$ & $7-14$ \\
\hline
\end{tabular}

1-Australian data from Chimonides (1987); 2-New Zealand data based on measurements of Hutton's type of A. swainsoni (= A. biseriata)

\section{Amathia lamourouxi Chimonides, 1987}

Amathia lamourouxi Chimonides, 1987: 322, figs 3A, 8C, 9A,C (cum syn.).

Material examined. BMNH; 1899.7.1.3, 'New Zealand', no other locality data.

Remarks. Chimonides (1987) established this species as a nomen novum for Amathia cornuta Lamouroux, 1816 (and of authors), preoccupied by Amathia cornuta (Lamarck, 1816), a different species. He established a neotype, based on a specimen from Port Phillip, Victoria; most other material in NHMUK came from southeastern Australia, including also Bass Strait and Sydney. The sole specimen said to have been collected in New Zealand is the only known such record; no specimens of $A$. lamourouxi have been found in the collections at NIWA or the Museum of New Zealand Te Papa Tongarewa.

The species is arborescent and supported by rhizoids, and terminal stolon segments that bear no autozooids are produced at the distal end of each autozooid cluster. Clusters comprise 11-15 autozooids, more or less in 5-7 pairs that are not spiralled on the stolon segments (see the key to the New Zealand amathiiform species, below).

Chimonides (1987) pointed out the obvious similarities of this species with Amathia australis (TenisonWoods, 1878). The only apparent difference is that A. australis is depicted as having both dichotomous and trichotomous branching, whereas all specimens examined by Chimonides are dichotomous. The whereabouts of Tenison-Woods' material is not known. If the characters of A. australis can be established with certainty, especially as regards branching, and demonstrated to be identical to A. lamourouxi, the earlier name would have priority.

\section{Amathia bicornis (Tenison-Woods, 1880)}

(Figs 22, 23)

Serialaria spiralis Tenison-Woods, 1878: 84, pl. 2. Non Amathia spiralis Lamouroux, 1816.

Amathia bicornis Tenison-Woods, 1880: 102; MacGillivray 1887: 221; MacGillivray 1889: 307, pl. 185, figs 1, 1a, 1b; MacGillivray 1895: 132, pl. A, fig. 2.

Amathia acervata: d'Hondt 1979: 10, 16; d'Hondt 1983: 65, fig. 36E; d'Hondt 1991: 163, 165; Gordon et al. 2009: 288. Non Amathia acervata Lamouroux, 1824.

Material examined. NIWA 84932, a dried beach-cast specimen attached to a stranded seaweed, Carpophyllum maschalocarpum (Sargassaceae), Makara, Wellington Region west coast, February 1983, collected by D.P. Gordon; specimen since reconstituted in trisodium phosphate and preserved in ethanol.

Description. Colony erect, bushy and densely branching, compact, to $35 \mathrm{~mm}$ high and wide, with a tuft of anchoring rhizoids proximally, brown. Stolon segments more or less straight but with an obvious sinuosity within the spiral autozooid cluster, the segments single or double between bifurcations; averaging $2.9 \mathrm{~mm}$ long (range 2.8-3.1 mm), each terminating at a regular dichotomy, the angle between the two branches generally $40-70^{\circ}$. Mean stolon width $0.148 \mathrm{~mm}$ (range $0.123-0.168 \mathrm{~mm}$; SD $0.013 \mathrm{~mm}$ ). Autozooid clusters disposed in tight spirals, each describing 1.25-1.5 turns around the internodal stolon segment, clockwise or anticlockwise along individual branches, comprising 16-19 'pairs' per cluster. Each cluster has its mean inception $1.46 \mathrm{~mm}$ (range 1.19-1.86 mm) 
from the bifurcation or from a septum, a mean linear distance of $1.48 \mathrm{~mm}$ (range 1.23-1.76 mm) on the stolon and terminates at the next bifurcation or septum, with the autozooid tips projecting beyond it; zooid cluster occupying c. $41-59 \%$ (mean 50\%) of stolon length. Autozooids all with paired hornlike processes, each an extension of the cuticularised outer distal corner, with a mean length (not including 'horns') of $0.539 \mathrm{~mm}$ (range $0.498-0.582 \mathrm{~mm}$ ), connate for their entire length except for the 'horns', with abutting edges of connate walls more obviously cuticularised than interior walls; zooid width averaging $0.151 \mathrm{~mm}$ (range $0.146-0.168 \mathrm{~mm}$ ). A rhizoid originating from a pore at the proximal end of the more proximal stolon segments, the pore occurring on the 'side' of the segment, passing down the collective stolon axis on the inside of the autozooidal spirals.

Remarks. According to d'Hondt (1979, 1983, 1991), A. bicornis Tenison-Woods, 1880, is a junior subjective synonym of Amathia acervata Lamouroux, 1824, but this synonymy is puzzling, since the original descriptions and stated provenances (Japan and southeastern Australia) of these species do not conform. Recent correspondence (30 June 2012) from Dr Jean-Loup d'Hondt has confirmed that this synonymy was based on a misunderstanding.

The occurrence of A. bicornis on an endemic New Zealand seaweed at a west coast locality not close to a port or a harbour appears to be natural, so the species is either a relatively recent self-introduction or it has long been present but overlooked.

\section{Amathia wilsoni Kirkpatrick, 1888}

(Figs 24, 25)

Amathia wilsoni Kirkpatrick, 1888: 18, pl. 2, figs 4, 4a; MacGillivray 1895: 139, pl. D, figs 2, 2a, 2b; Jelly 1889: 14; Macken 1956: 22, fig. 4; d'Hondt 1983: 67, fig. 36A; Chimonides 1987: 327, figs 4D, 10C, D; Gordon 1986: 17, fig. 4A,B; Gordon et al. 2009: 288.

Material examined. Museum of New Zealand Te Papa Tongarewa: NMNZ ZPz. 80, Karaka Bay, Wellington, August 1930. NIWA: Unregistered material from Stn B493, 45 34.4' S, 166 39.1' E, Breaksea Sound, Fiordland, 84 m, 8 June 1961; Stn Z9689, 34.324 S, 172.826 E, north of Spirits Bay, Northland, 63 m, 27 January 1999; Stn Z9702, 34.316 ${ }^{\circ}$ S, $172.793^{\circ}$ E, north of Spirits Bay, Northland, 68 m, 28 January 1999. Natural History Museum, London: NHMUK 99.7.1.4345, 4348, 4348b (labelled “Amathia delicatissima"), Busk Collection, Lyall Bay, Cook Strait, New Zealand (collected by Dr David Lyall, of H.M.S. Acheron, which did survey work in 1847).

Remarks. Gordon (1986) noted that this is the commonest and most widespread of the known Amathia species in New Zealand, ranging from The Three Kings Islands to Fiordland and that large quantities are often washed ashore on Wellington south coast beaches after southerly storms. Its delicate, creamy-whitish-transparent, fluffy appearance underwater and distinctive branch tri- and tetrachotomies make this species instantly recognisable.

\section{Genus Bowerbankia Farre, 1837}

\section{Bowerbankia citrina (Hincks, 1877) sensu lato}

(Figs 26, 27)

Valkeria citrina Hincks, 1877: 215.

Bowerbankia citrina: Hincks 1880: 524, pl. 76, figs 6-8; Prenant \& Bobin 1956: 300, figs 122(7), 135, 136(1-3); d'Hondt 1983: 61, fig. 32E; Hayward 1985: 142, fig. 48; De Blauwe 2009: 86, figs 66-68; Souto et al. 2011: 2549, figs 5, 6, 7b.

Material examined. NIWA 84933, low tide under rocks, north-central Porirua Harbour under the penultimate boatshed along Onepoto Road, collected by D.P. Gordon, 7 February 2012.

Description. Colony with straggling erect branches attached by rhizoids, to about $5 \mathrm{~cm}$ high. Stolon segments more or less straight to slightly bent, averaging $1.95 \mathrm{~mm}$ long (range $1.86-2.07 \mathrm{~mm}$ ), each producing a daughter branch at an angle of 30-70 . Mean stolon width $0.144 \mathrm{~mm}$ (range $0.123-0.190 \mathrm{~mm}$ ). Autozooid clusters disposed in loose, more-or-less anticlockwise half-spirals at the distal ends of stolon segments, with about 18-24 autozooids in each cluster. Each cluster has its mean inception about $0.79-0.86 \mathrm{~mm}$ from a bifurcation, a mean linear distance of $1.42 \mathrm{~mm}$ (range 1.23-1.68 mm) on the stolon and terminates at the next bifurcation, with the autozooid tips 
projecting beyond it. Autozooids transparent, with a mean length of $0.522 \mathrm{~mm}$ (range $0.437-0.616 \mathrm{~mm}$ ), their orifices somewhat squared when retracted; zooid width averaging $0.142 \mathrm{~mm}$ (range $0.112-0.168 \mathrm{~mm}$ ), tentacles 8 , each with a distinctive line of yellow pigment running the full length.
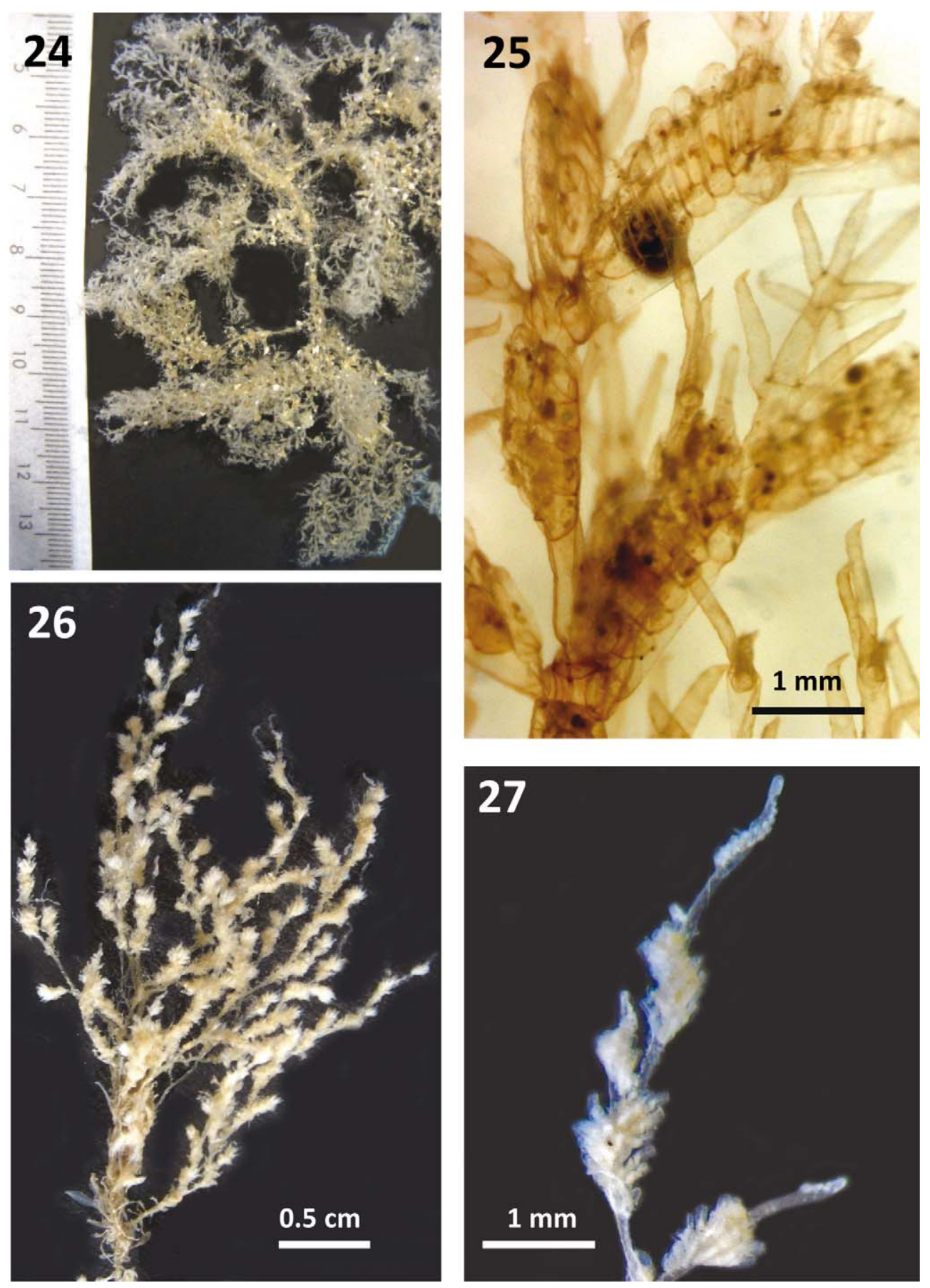

FIGURES 24-27, Amathia wilsoni Kirkpatrick, 1888. 24, general appearance of colony, from NIWA Stn Z9689, 34.324 S, $172.826^{\circ}$ E, 63 m depth, Three Kings Islands, North Island; 25, close-up of specimen 99.7.4345 (on slide), Busk Collection, Natural History Museum, London, from Lyall Bay, Wellington, showing disposition of autozooidal clusters and terminal kenozooidal stolon segments. 26, 27, Bowerbankia citrina (Hincks, 1877) sensu lato, from Porirua Harbour, North Island.

Remarks. This is the first record of an 'amathiiform' Bowerbankia from New Zealand. Its most distinctive feature when viewed alive by light microscopy is the strong lemon-yellow colour that resides in the tentacles of the polypide, exactly as shown in the photographs of De Blauwe (2009) and Souto et al. (2011). The colour is not seen in preserved material. A specimen was sent to the laboratory of Dr Karin Hoch Fehlauer-Ale at CEBIMar-USP (Brazil) for DNA sequencing, to be compared with B. citrina from Wales and Spain. Based on preliminary 
phylogenetic analyses of the mitochondrial genes, large ribosomal RNA subunit (16S) and cytochrome $c$ oxidase subunit 1 (COI), Dr Fehlauer-Ale suggests: "the specimen from New Zealand probably represents a new species of Bowerbankia, sister to the European clade of $B$. citrina" and "it seems we might have a complex of cryptic species under the name B. citrina."

Waeschenbach et al. (2012) noted that an unnamed species of Amathia nested within the cluster of Bowerbankia species that they sequenced on the basis of two nuclear ribosomal and five mitochondrial genes (including 16S rRNA and COI), with B. citrina as sister to the Amathia in the distalmost part of the tree. Since Amathia was the first-named genus, it suggests that the genus Bowerbankia may be subsumed in Amathia but, as the authors noted, taxon sampling is needed, which would clarify the relationships among the morphological extremes in both genera. Even though autozooids are disposed in spirals on the distal half of each stolon segment in Bowerbankia pustulosa (Ellis \& Solander, 1786) and B. citrina, these species differ quite obviously from Amathia because of the loose, non-connate nature of the autozooids, which also lack any differential cuticularisation of the body wall. The genetic data imply that these characters evolved more than once in Amathia, in which seriation of autozooids in the clusters, in actual or slightly offset pairs, is such a striking feature.

New Zealand B. citrina sensu lato was first noted in Porirua Harbour in March 2011. Rather less of it was found in 2012, at the same locality, but the species has the potential to spread within New Zealand. The Porirua Harbour specimens were somewhat fouled by epizoic diatoms, tiny red algae and two other ctenostome bryozoans when collected in 2012; in New Zealand the latter ctenostome species are conventionally referred to as Bowerbankia gracilis Leidy, 1855 and Buskia nitens Alder, 1857 (but detailed morphological comparisons and gene sequencing of topotypic material are necessary to establish their identity with certainty).

\section{A note on the purported record of Amathia lendigera in New Zealand}

Macken (1956) examined a specimen of A. lendigera in the collection of the Museum of New Zealand Te Papa Tongarewa (registered as Pz. 79) that was noted to have been collected from Napier by Miss E.M. Williams in 1935. We have examined this specimen (which was in a vial and dried but is now preserved in $70 \%$ ethanol after having been reconstituted in aqueous trisodium phosphate). It is certainly A. lendigera, not either of the lendigera look-alikes named by Chimonides (1987), i.e. A. intermedis and A. guernseii. Overlooked by Macken, however, were tiny colonies of two other bryozoans growing on A. lendigera, viz. Electra pilosa (Linnaeus, 1767) and Scrupocellaria scruposa (Linnaeus, 1758). The only similar spinose electriform species in New Zealand is Electra scuticifera Nikulina, 2008 (previously wrongly attributed to E. pilosa), whereas that in the sample conforms fully to E. pilosa; likewise the only mainland-coast species of Scrupocellaria in New Zealand is S. ornithorhyncus Thomson, 1858, whereas that in the sample conforms fully to $S$. scruposa.

The co-occurrence of these three species, all of which are well-known in Europe, mitigates strongly against the sample having come from Napier and we suspect that either the purported provenance was based on a misunderstanding or that the specimen was subsequently mislabelled in the Te Papa collection; there are quite a number of bryozoan samples from Britain at Te Papa and it appears likely that the A. lendigera should be counted as one of them.

While it is not impossible that the specimen of A. lendigera was collected directly from the hull of a ship at the port of Napier in 1935, it seems unlikely that the small, non-reproductive epizoic colonies of the two other species, which appear to have been alive at the time of collection, would have survived the passage from European waters to New Zealand via the tropics. [The species is not known to be naturalised outside of Europe, so neither it, nor indeed its epizoites, can have been picked up through a temporary stoppage at a foreign port while en route to New Zealand.] Our conclusion is that the sole record of A. lendigera in New Zealand was based on a misunderstanding or labelling error and does not represent a failed introduction of an alien species.

\section{Discussion}

Based upon his study of fifteen Amathia species with no spiralling of autozooids about the stolon (or weakly so owing to a twisting of the stolon segment itself), Chimonides (1987) listed seven diagnostic characters useful for 
discrimination, ranking them in order of reliability: 1) budding pattern of stolons; 2) development of any kenozooidal processes or rhizoids and their orientation; 3) arrangement of autozooids about the stolons; 4) autozooidal thickening; 5) profile of autozooids and stolons; 6) number of autozooids and proportion of stolon occupied by autozooids; and 7) dimensions of components. With respect to character 1 , he ascertained that the branching pattern remains remarkably consistent within species. Characters 1-3 in combination give rise to characteristic colony shapes that, with familiarisation, allow identification of species by casual inspection. Fehlauer-Ale et al. (2011) noted that the expression of rhizoids can be inconstant within some species.

The balance of described Amathia taxa includes 12 species in which there is significant $\left(>100^{\circ}\right)$ spiralling of zooid clusters about the stolon segments. As with the non-spiralling species, these also constitute a range of colony morphologies with different budding patterns. The differences among these species are expressed in the following key, which also includes Amathia gracei $\mathbf{n}$. sp., Amathia chimonidesi $\mathbf{n}$. sp. and Amathia similis $\mathbf{n}$. sp.

\section{Key to the spiralled species of Amathia and Amathia-like Bowerbankia*:}

1. Autozooids not connate, their body wall not differentially thickened (Bowerbankia) $\ldots \ldots \ldots \ldots \ldots \ldots$ Autozooids connate for at least half their length, body wall differentially thickened (Amathia) $\ldots \ldots \ldots \ldots$

2. Polypide with yellow tentacles; biseriality weakly developed $\ldots \ldots \ldots \ldots \ldots \ldots \ldots \ldots \ldots \ldots \ldots \ldots \ldots$ Polypide with unpigmented tentacles; biseriality moderately developed $\ldots \ldots \ldots \ldots \ldots \ldots \ldots \ldots \ldots \ldots \ldots \ldots$. $\ldots \ldots$. $\ldots \ldots$. $\ldots \ldots \ldots$

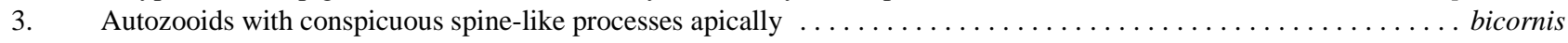

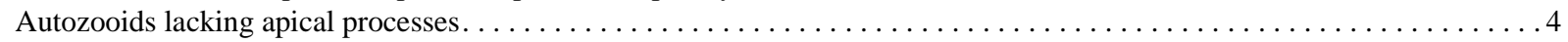

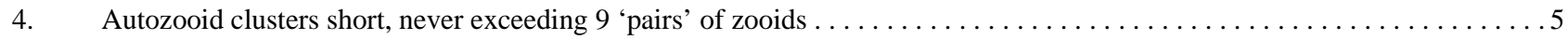

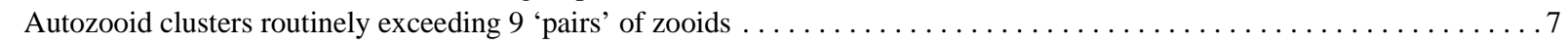

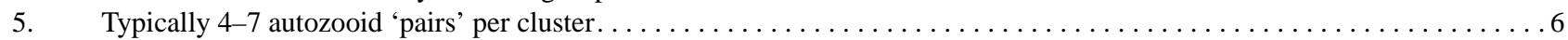

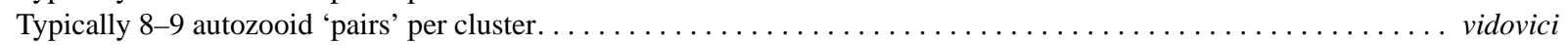

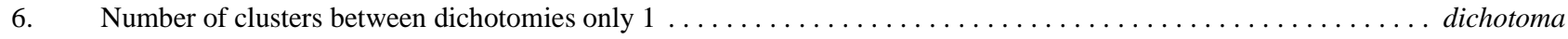

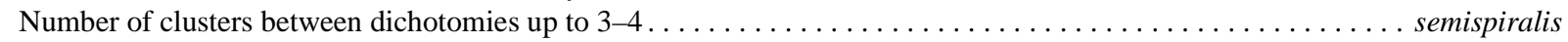

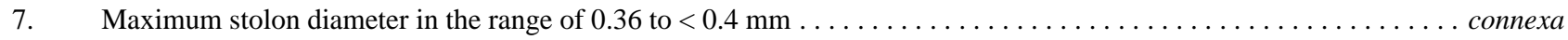

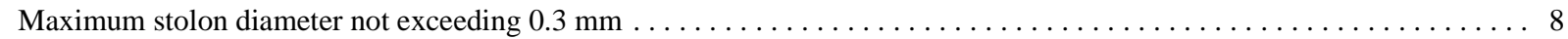

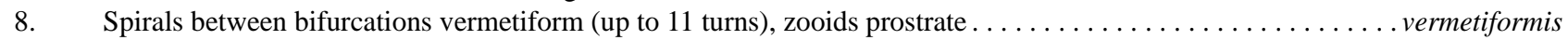

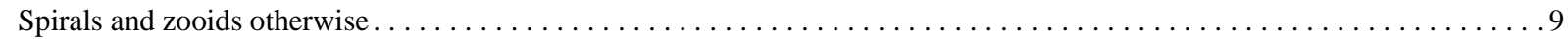

9. Spirals subhorizontal in lateral view, continuous, sheet-like, concealing branches $\ldots \ldots \ldots \ldots \ldots \ldots$. . . . . . . convoluta

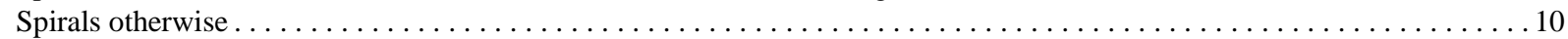

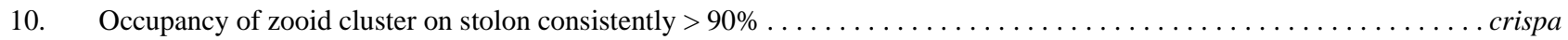

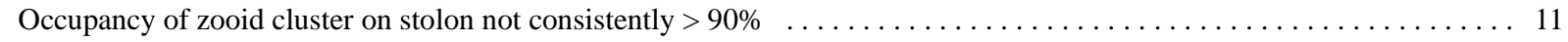

11. Occupancy of zooid cluster on stolon in range of $36-49 \% \ldots \ldots \ldots \ldots \ldots \ldots \ldots \ldots \ldots \ldots \ldots \ldots \ldots$ simis n. sp.

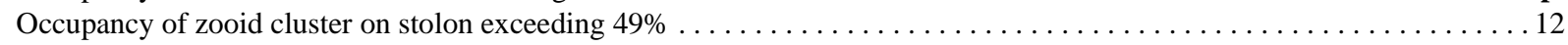

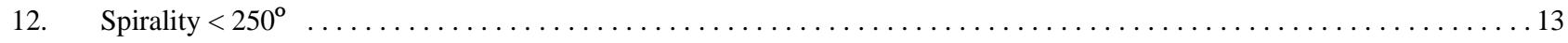

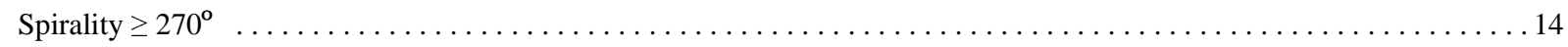

13. Zooid pairs $15-21$, occupancy of cluster on stolon $53-67 \% \ldots \ldots \ldots \ldots \ldots \ldots \ldots \ldots \ldots \ldots$. . . . . . . . minoricensis Zooid pairs 20-27, occupancy of cluster on stolon $68-73 \% \ldots \ldots \ldots \ldots \ldots \ldots \ldots \ldots \ldots \ldots \ldots \ldots \ldots$ tortuosa

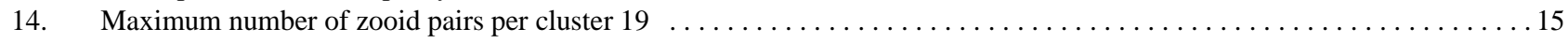

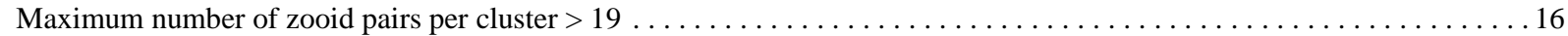

15. Stolon diameter $0.09-0.14 \mathrm{~mm}$, yellow-pigmented $\ldots \ldots \ldots \ldots \ldots \ldots \ldots \ldots \ldots \ldots \ldots \ldots \ldots \ldots \ldots \ldots \ldots$ distans Stolon diameter $0.22-0.25 \mathrm{~mm}$ diameter, no yellow pigment $\ldots \ldots \ldots \ldots \ldots \ldots \ldots \ldots \ldots \ldots \ldots \ldots \ldots \ldots$ brailiensis

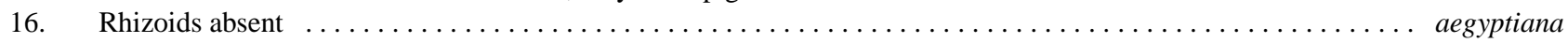

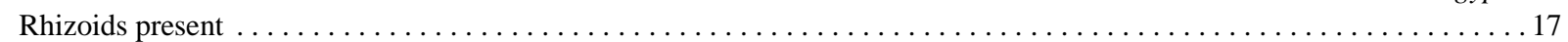

17. Autozooidal spiral proximal to bifurcation $270-315^{\circ} \ldots \ldots \ldots \ldots \ldots \ldots \ldots \ldots \ldots \ldots \ldots \ldots$ semiconvoluta

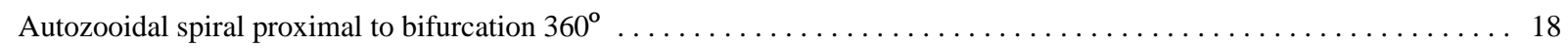

18. Autozooid pairs $24-32$, spirality only clockwise $\ldots \ldots \ldots \ldots \ldots \ldots \ldots \ldots \ldots \ldots \ldots \ldots \ldots \ldots \ldots \ldots \ldots \ldots \ldots \ldots$ chimonidesi $\mathbf{n} . \mathbf{s p}$. Autozooid pairs $16-23$, spirality (apparently) only anticlockwise $\ldots \ldots \ldots \ldots \ldots \ldots \ldots \ldots \ldots \ldots \ldots$ gracei $\mathbf{n} . \mathbf{s p}$.

*Not including A. acervata from Japan, which has yet to be properly characterised based on fresh material and a rehydrated fragment of the type specimen. 


\section{Key to the species of Amathia and 'amathiiform' Bowerbankia in New Zealand}

1. Autozooids not connate, their body wall not differentially thickened . . . . . . . . . . . . . . . Bowerbankia citrina s.l. Autozooids connate for at least half their length, with differential cuticularisation (Amathia) $\ldots \ldots \ldots \ldots \ldots$

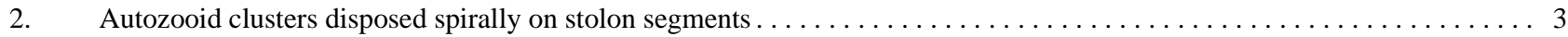

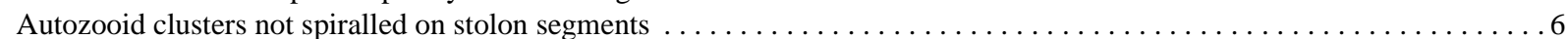

3. Autozooids with paired distal 'spines' $\ldots \ldots \ldots \ldots \ldots \ldots \ldots \ldots \ldots \ldots \ldots \ldots \ldots \ldots \ldots \ldots \ldots \ldots \ldots \ldots$. $\ldots \ldots \ldots$. $\ldots \ldots \ldots$

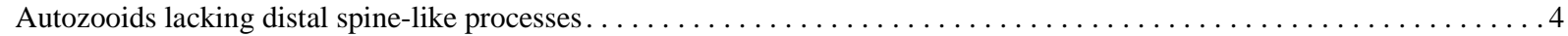

4. Autozooidal clusters occupying $<50 \%$ of stolon length $\ldots \ldots \ldots \ldots \ldots \ldots \ldots \ldots \ldots \ldots \ldots \ldots$ similis $\mathbf{n} . \mathbf{s p}$.

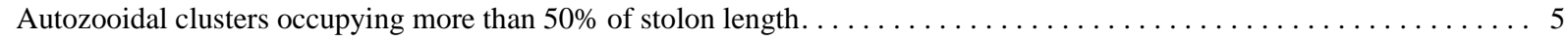

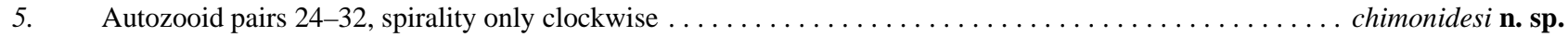
Autozooid pairs $16-23$, spirality only anticlockwise $\ldots \ldots \ldots \ldots \ldots \ldots \ldots \ldots \ldots \ldots \ldots \ldots \ldots \ldots \ldots \ldots \ldots \ldots$ gracei $\mathbf{n}$ sp.

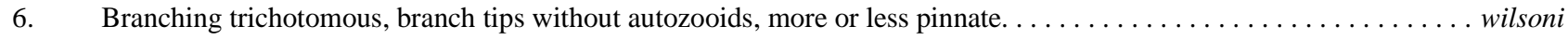

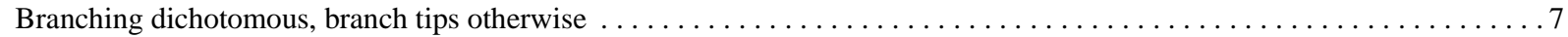

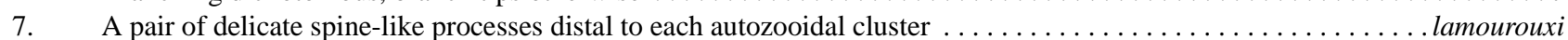
No delicate spine-like processes distal to each autozoodal cluster $\ldots \ldots \ldots \ldots \ldots \ldots \ldots \ldots \ldots \ldots \ldots \ldots \ldots \ldots$

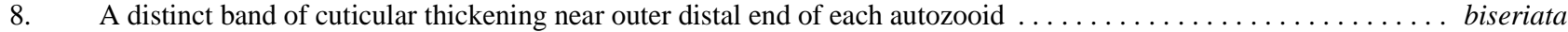
No such distinct band of cuticular thickening . . . . . . . . .

Amathia is a highly distinctive, easily recognisable genus but some of its species have been and continue to be confused and, as indicated in the preceding account, undescribed species have the potential to be shoe-horned into existing species. Gene sequencing holds much promise in providing supplementary molecular characters and should aid in speedier, unequivocal identification in the future, as well as highlighting the existence of undescribed cryptic species. Following from the work of Waeschenbach et al. (2012), if it should be found that species of Amathia and Bowerbankia consistently nest together and that the genera should be merged, Amathia Lamouroux, 1812 would take precedence over Bowerbankia Farre, 1837.

\section{Acknowledgments}

We are grateful to Dr Roger V. Grace for a specimen of A. chimonidesi n. sp. from Auckland Harbour. Drs Kevin Tilbrook (Museum of Tropical Queensland, Townsville), Jean-Loup d'Hondt (Muséum National d'Histoire Naturelle, Paris) and Masato Hirose (National Museum of Nature and Science, Tsukuba) gave advice and/or loaned specimens. Dr Karin Hoch Fehlauer Ale (Universidade de São Paulo) kindly arranged for molecular sequencing of some samples in her laboratory and provided information on the genetic status of New Zealand Bowerbankia citrina (sensu lato). The New Zealand Ministry of Primary Industries gave permission to use the data associated with specimens collected by surveillance.

\section{References}

Alder, J. (1857) A Catalogue of the Zoophytes of Northumberland and Durham. F. \& W. Dodsworth, Newcastle-on-Tyne. 72 pp.

Anon. (2005) Cheltenham Beach on top of clean-up list. The Devonport Flagstaff, 7.

Busk, G. (1852) An account of the Polyzoa, and sertularian zoophytes, collected in the voyage of the Rattlesnake, on the coasts of Australia and the Louisiade Archipelago, \&c. In: MacGillivray, J. (Ed.), Narrative of the voyage of H.M.S. Rattlesnake, commanded by the late Captain Owen Stanley during the years 1846-50, including discoveries and surveys in New Guinea, the Louisiade Archipelago, etc : to which is added Mr. E.B. Kennedy's expedition for the exploration of the Cape York Peninsula [including Mr W. Carron's narrative] Volume 1. W. Boone, London, pp. 343-402, pl. 1.

Busk, G. (1886) Report on the Polyzoa collected by H.M.S. Challenger during the years 1873-76. Part II. - The Cyclostomata, Ctenostomata, and Pedicellinea. Report on the Scientific Results of the Voyage of H.M.S. Challenger, Zoology, 17[3](50), iviii, $1-47,10$ pls.

Calvet, L. (1911) Sur deux espèces nouvelles de Bryozoaires de la Méditerrannée: Idmonea arborea n. sp. et Amathia pruvoti n. sp. Archives de Zoologie expérimentale et générale, sér. 5, 8 (Notes et Revue, 3), 57-61.

Chimonides, P.J. (1987) Notes on some species of the genus Amathia (Bryozoa, Ctenostomata). Bulletin of the British Museum (Natural History), Zoology, 52, 307-358.

De Blauwe, H. (2009) Mosdiertjes van de Zuidelijke Boct van de Noordzee. Determinatie voor België en Nederland. VLIZ, 
Ostend, $445 \mathrm{p}$.

Delle Chiaje, S. (1822) Memorie sulla Storia e Notomia degli Animali senza Vertebre del Regno di Napoli. Fratelli Fernandes, Napoli, 109 pls.

Ehrenberg, C.G. (1829) Symbolae physicae, seu icones et descriptiones corporum naturalium novorum aut minus cognitorum, quae ex itineribus per Libyam, Aegyptum, Nubiam, Dongalam, Syriam, Arabiam et Habessiniam à P. C. Hemprich et C. G. Ehrenberg à studio annis 1820-25 redierunt à pars Zoologica, C.G. Ehrenberg, ed. Berolini., Animalia evertebrata exclusis Insectis. Berlin. Vol. 4, 10 pls.

Ellis, J. \& Solander, D. (1786) The Natural History of many curious and uncommon Zoophytes, collected from various parts of the globe, by the late John Ellis, Esq. F. R. S., Soc. Reg. Upsal. Soc., author of the natural history of English corallines, and other works. Systematically arranged and described by the late Daniel Solander, M. D. F. R. S. \&c. Benjamin White \& Son, London. xii +208 p., 63 pls.

Farre, A. (1837) Observations on the minute structure of some of the higher forms of Polypi, with views of a more natural arrangement of the class. Philosophical Transactions of the Royal Society of London, 127, 387-426, pls 20-27. http://dx.doi.org/10.1098/rstl.1837.0024

Fehlauer-Ale, K.H., Vieira, L.M. \& Winston, J.E. (2011) Molecular and morphological characterization of Amathia distans Busk and Amathia brasiliensis Busk (Bryozoa: Ctenostomata) from the tropical and subtropical Western Atlantic. Zootaxa, 2962, 49-62.

Goldstein, J.R.Y. (1879) On a new species of Polyzoa. The Quarterly Journal of the Microscopical Society of Victoria, 1, 1920, pl. 3, fig. 5.

Gordon, D.P. (1967) A report on the ectoproct Polyzoa of some Auckland shores. Tane (Journal of the Auckland University Field Club), 13, 43-76.

Gordon, D.P. (1986) The marine fauna of New Zealand: Bryozoa: Gymnolaemata (Ctenostomata and Cheilostomata Anasca) from the western South Island continental shelf and slope. New Zealand Oceanographic Institute Memoir, 95, 1-121.

Gordon, D.P., Hosie, A.M. \& Carter, M.C. (2008) Post-2000 detection detection of warm-water alien bryozoan species in New Zealand - the significance of recreational vessels. In: Hageman, S.J., Key, M.M. Jr \& Winston, J.E. (Eds), Bryozoan Studies 2007. Virginia Museum of Natural History Special Publication, 15, 37-48.

Gordon, D.P. \& Mawatari, S.F. (1992) Atlas of marine-fouling Bryozoa of New Zealand ports and harbours. Miscellaneous Publications, New Zealand Oceanographic Institute, 107, 1-52.

Gordon, D.P., Taylor, P.D. \& Bigey, F.P. (2009) Phylum Bryozoa — moss animals, sea mats, lace corals. In: Gordon, D.P. (Ed.), New Zealand Inventory of Biodiversity, Volume One: Radiata, Lophotrochozoa, Deuterostomia. Canterbury University Press, Christchurch, pp. 271-297.

Hamilton, A. (1898) A list of Recent and fossil Bryozoa collected in various parts of New Zealand. Transactions of the New Zealand Institute, 30, 192-199.

Harger, J.R.E. (1964) The settlement and development of fouling communities on vertical buoyant surfaces in the Auckland Harbour with notes on an adjacent wharfpile fauna. MSc thesis, University of Auckland. xiii + 99 p., 86 pls.

Harmer, S.F. (1915) The Polyzoa of the Siboga Expedition. Part I. Entoprocta, Ctenostomata and Cyclostomata. SibogaExpeditie, 28a, i-vi, 1-180, pls 1-12.

Harmer, S.F. (1926) The Polyzoa of the Siboga Expedition. Part II. Cheilostomata Anasca Siboga-Expeditie, 28b, viii, 181501, pls 13-34.

Hayward, P.J. (1985) Ctenostome bryozoans. Keys and notes for the identification of the species. Synopses of the British Fauna, n.s., 33: 1-169.

Heller, C. (1867) Die Bryozoen des adriatischen Meeres. Verhandlungen der zoologisch-botanischen Gesellschaft in Wien, 17, 77-136, pls 1-6.

Hincks, T. (1877) On British Polyzoa.- Part I. Annals and Magazine of Natural History, ser. 4, 20, 212-218.

Hincks, T. (1880) A History of the British Marine Polyzoa. Van Voorst, London, cxli + 601 p., 83 pls. [In 2 vols.]

Hondt, J.-L. d' (1979) Révision des Bryozoaires de Lesueur et Péron conservés dans les collections du Muséum National d'Histoire Naturelle de Paris. Bulletin trimestriel de la Société Géologique de Normandie et des Amis du Muséum du Havre, 66, 9-24.

Hondt, J.-L. d' (1983) Tabular keys for identification of the Recent ctenostomatous Bryozoa. Memoires de l'Institut Océanographique, Monaco, 14, 1-134.

Hondt, J.-L. d' (1991) The Bryozoa of the Lamouroux Collection. In: Bigey, F.P. (Ed.), Bryozoaires Actuels et Fossiles : Bryozoa Living and Fossil. Bulletin de la Société des Sciences Naturelles de l'Ouest de la France, Mémoire HS, 1, $161-168$.

Hutton, F.W. (1873) Catalogue of the Marine Mollusca of New Zealand, with diagnoses of the species. Government Printer, Wellington, $\mathrm{xx}+116$ p., 1 pl. [Polyzoa, pp. xiii, 87-104.]

Hutton, F.W. (1880) Manual of the New Zealand Mollusca. A systematic and descriptive catalogue of the marine and land shells, and of the soft mollusks and Polyzoa of New Zealand and the adjacent islands. James Hughes, Wellington, xvi + iii + 224 p. [Polyzoa, pp. iii + 179-199.]

Hutton, F.W. (1891) Revised list of the marine Bryozoa of New Zealand. Transactions and Proceedings of the New Zealand Institute, 23, 102-107.

Hutton, F.W. (1904) Index Faunae Novae Zealandiae. Dulau \& Co., London, viii + 372 p. [Polyzoa, pp. 293-299.]

Jelly, E.C. (1889) A Synonymic Catalogue of Recent marine Bryozoa. Dulau \& Co., London, xv + 322 p. 
Johnston, G. (1840) Miscellanea zoologia. Description of a new genus of British zoophyte. Annals and Magazine of Natural History, 5, 272-274.

Johnston, G. (1847) A History of the British Zoophytes. 2nd edn. John Van Voorst, London, xvi + 488 p., 74 pls (in 2 vols).

Kirchenpauer, G.H. (1869) Neue Bryozoen. Museum Godeffroy Catalog, 4, 25-34.

Kirkpatrick, R. (1888) Polyzoa from Port Phillip. Annals and Magazine of Natural History, ser. 6, 2, 12-21, pl. 2.

Krauss, C.F.F. (1837) Beitrag zur Kenntniss der Corallineen und Zoophyten der Südsee, nebst abbildungen der neuen Arten. E. Schweizerbart, Stuttgart, 37 p., 1 pl.

Lamarck, J.B.P.A. de (1816) Histoire naturelle des Animaux sans Vertèbres ... précédé d'une introduction offrant la determination des caractères essentiels de l'animal, sa distinction du végétal et des autres corps naturels, enfin, l'exposition des principes fondamentaux de la zoologie. Tome 2, Polypes. Verdière, Paris, 568 p.

Lamouroux, J.V.F. (1812) Extrait d'un mémoire sur la classification des Polypiers coralligènes non entièrement pierreux. Nouveau Bulletin des Sciences, par la Société Philomathique de Paris, 3, 181-188.

Lamouroux, J.V.F. (1816) Histoire des Polypiers coralligènes flexibles, vulgairement nommés Zoophytes. Poisson, Caen, 560 p.

Lamouroux, J.V.F. (1824) Amathie. In: Lamouroux, J.V.F., Bory de Saint Vincent, J.B. \& Eudes-Deslongchamps, J.A. (Eds), Encyclopédie d'Histoire naturelle des Zoophytes ou Animaux rayonées. Tome 95. Agasse, Paris, pp. 42-45.

Leidy, J. (1855) Contributions towards a knowledge of the marine invertebrate fauna of the coasts of Rhode Island and New Jersey. Journal of the Academy of Natural Sciences of Philadelphia, n.s., 3, 135-152.

Linnaeus, C. (1758) Systema Naturae per regna tria naturae, secundum classes, ordines, genera, species, cum caracteribus, differentiis, synonymis, locis. Editio decima. Laurentii, Salvii, Holmiae. 824 p.

Linnaeus, C. (1767) Systema Natura per regna tria naturae, secundum classes, ordines, genera, species cum caracteribus, differentiis, synonymis, locis. Tomus I. Regnum animale. Editio duodecima reformata. Salvii, Holmiae. $1237 \mathrm{p}$.

MacGillivray, P.H. (1887) Descriptions of new, or little-known, Polyzoa. Part XII. Transactions and Proceedings of the Royal Society of Victoria, 22, 179-186, 2 pls.

MacGillivray, P.H. (1889) Polyzoa. In: McCoy, F., Prodromus of the Zoology of Victoria; figures and descriptions of the living specis of all classes of the Victorian indigenous animals. Volume II. (Decades XI. to XX.). Government Printer, Melbourne, pp. 307-323, pls 185-187.

MacGillivray, P.H. (1890) Descriptions of new, or little-known, Polyzoa. Part XIII. Transactions and Proceedings of the Royal Society of Victoria, n.s., 2, 106-110, pls 4, 5.

MacGillivray, P.H. (1895) On the Australian species of Amathia. Proceedings of the Royal Society of Victoria, n.s., 7, 131-140, pls A-D.

Macken, J. (1956) Studies on the Recent Bryozoa of New Zealand: I-On some members of the Ctenostomata. Records of the Dominion Museum, 3, 19-26.

Morton, J. (2004) Seashore Ecology of New Zealand and the Pacific. David Bateman, Auckland, 504 p.

Morton, J. \& Miller, M. (1968) The New Zealand Sea Shore. Collins, Auckland \& London, 638 p.

Nikulina, E.A. (2008) Electra scuticifera sp. nov.: Redescription of Electra pilosa from New Zealand as a new species (Bryozoa, Cheilostomata). Schriften des Naturwissenschaftlichen Vereins für Schleswig-Holstein, 70, 91-98.

Prenant, M. \& Bobin, G. (1956) Bryozoaires. Première partie: Entoproctes, Phylactolèmes, Cténostomes. Faune de France, 60, $1-398$.

Sherborn, C.D. (1922) Index Animalium 1801-1850. Part. I. Introduction, bibliography and index A-Aff. Trustees of the British Museum, London, cxxxi $+128 \mathrm{pp}$.

Souto, J., Fernández-Pulpeiro, E. \& Reverter-Gil, O. (2010) The genus Amathia Lamouroux (Bryozoa: Ctenostomata) in Iberian waters. Cahiers de Biologie marine, 51, 181-195.

Souto, J., Fernández-Pulpeiro, E. \& Reverter-Gil, O. (2011) Presence of rhizoids in two species of the genus Bowerbankia (Bryozoa: Ctenostomata) and their systematic relevance. Journal of Natural History, 45, 2543-2557. http://dx.doi.org/10.1080/00222933.2011.597003

Tenison-Woods, J.E. (1877[1878]) On some new Australian Polyzoa. Journal and Proceedings of the Royal Society of New South Wales, 11, 83-84, 2 pls.

Tenison-Woods, J.E. (1880) On the genus Amathia of Lamouroux, with a description of a new species. Transactions of the Royal Society of Victoria, 16, 89-118, 1 pl.

Thomson, W.T.C. (1858) On new genera and species of Polyzoa in the collection of Professor W.H. Harvey. Natural History Review and Quarterly Journal of Science, 5, 134-147.

Verrill, A.E. (1873) Report on the invertebrates of Vineyard Sound and the adjacent waters, with an account of the physical characters of the region. Report of the US Fish Commission, 1, 295-778.

Voigt, E. (1972) Amathia immurata n. sp., ein durch Bioimmuration erhaltenes ctenostomes Bryozoon aus der Maastrichter Tuffkreide. Paläontologische Zeitschrift, 46, 87-92, pl. 17.

Waeschenbach, A., Taylor, P.D. \& Littlewood, D.T.J. (2012) A molecular phylogeny of bryozoans. Molecular Phylogenetics and Evolution, 62, 718-735. http://dx.doi.org/10.1016/j.ympev.2011.11.011

Waters, A.W. (1887a) Bryozoa from New South Wales, north Australia, \&c. Part II. Annals and Magazine of Natural History, ser. 5, 10, 181-203, pls 5, 6 .

Waters, A.W. (1887b) Bryozoa from New South Wales, north Australia, \&c. Part III. Annals and Magazine of Natural History, ser. $5,10,253-265$, pl. 7. 